Prepared in cooperation with the Florida Department of Agriculture and Consumer Services, and the Southwest Florida Water Management District

\title{
Pesticides and Nitrate in Groundwater Underlying Citrus Croplands, Lake Wales Ridge, Central Florida, 1999-2005
}

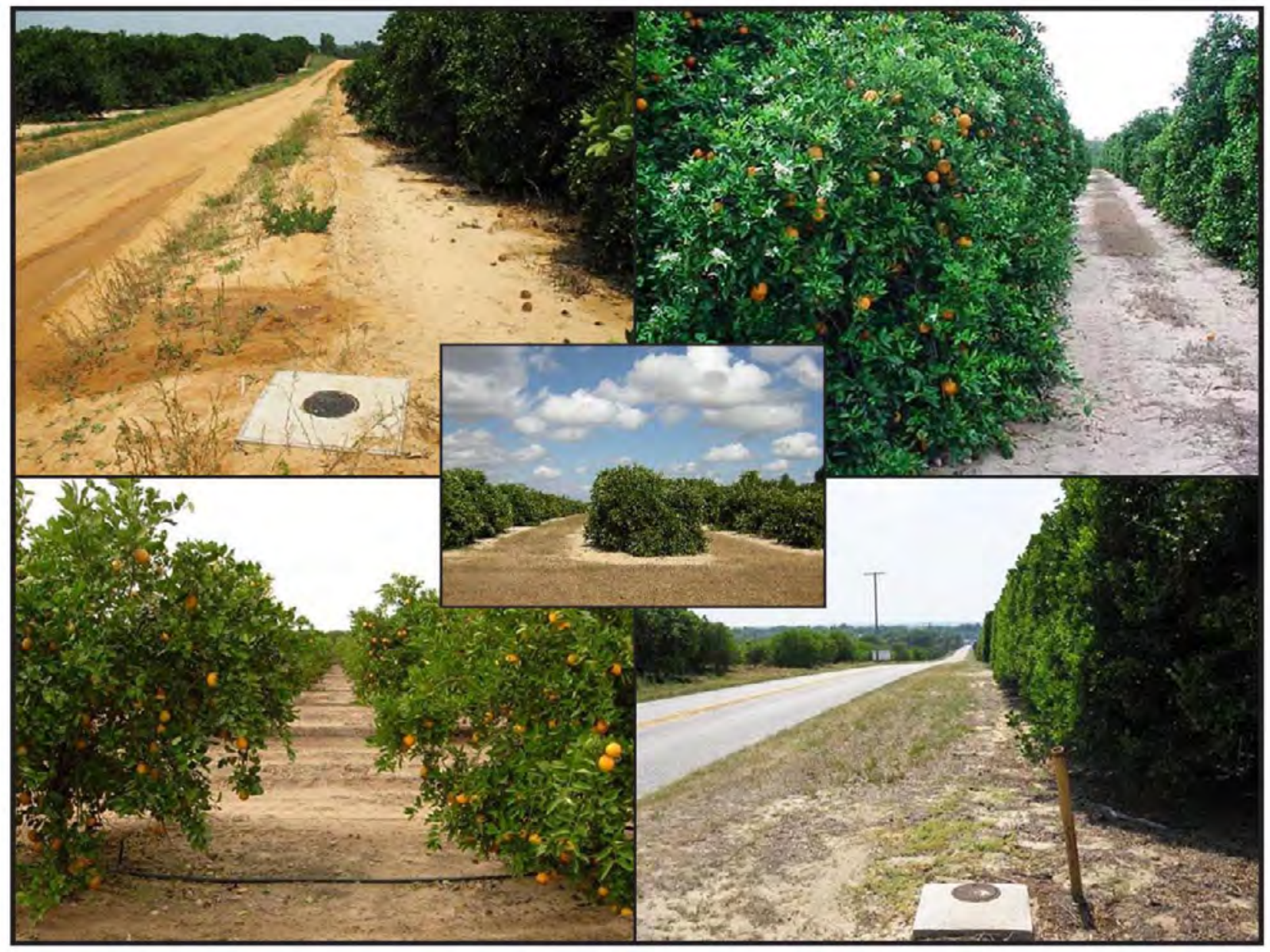

Open-File Report 2013-1271 
Cover: Citrus orchards in the vicinity of Lake Wales Ridge Monitoring Network wells, courtesy of the Southwest Florida Water Management District. Wellheads of monitoring wells, which were flushmounted at ground surface, appear in the upper left and lower right photographs. 


\section{Pesticides and Nitrate in Groundwater Underlying Citrus Croplands, Lake Wales Ridge, Central Florida, 1999-2005}

By A.F. Choquette

Prepared in cooperation with the Florida Department of Agriculture and

Consumer Services, and the Southwest Florida Water Management District

Open-File Report 2013-1271 


\title{
U.S. Department of the Interior SALLY JEWELL, Secretary
}

\author{
U.S. Geological Survey \\ Suzette M. Kimball, Acting Director
}

U.S. Geological Survey, Reston, Virginia: 2014

For more information on the USGS - the Federal source for science about the Earth, its natural and living resources, natural hazards, and the environment, visit http://Www.usgs.gov or call 1-888-ASK-USGS.

For an overview of USGS information products, including maps, imagery, and publications, visit $h t t p: / / w w w . u s g s . g o v / p u b p r o d$

To order this and other USGS information products, visit http://store.usgs.gov

Any use of trade, product, or firm names is for descriptive purposes only and does not imply endorsement by the U.S. Government.

Although this report is in the public domain, permission must be secured from the individual copyright owners to reproduce any copyrighted materials contained within this report.

Suggested citation:

Choquette, A.F., 2014, Pesticides and nitrate in groundwater underlying citrus croplands, Lake Wales Ridge, central Florida, 1999-2005: U.S. Geological Survey Open-File Report 2013-1271, 28 p.,

http://dx.doi.org/10.3133/ofr20131271

ISSN 2331-1258 (online) 


\section{Contents}

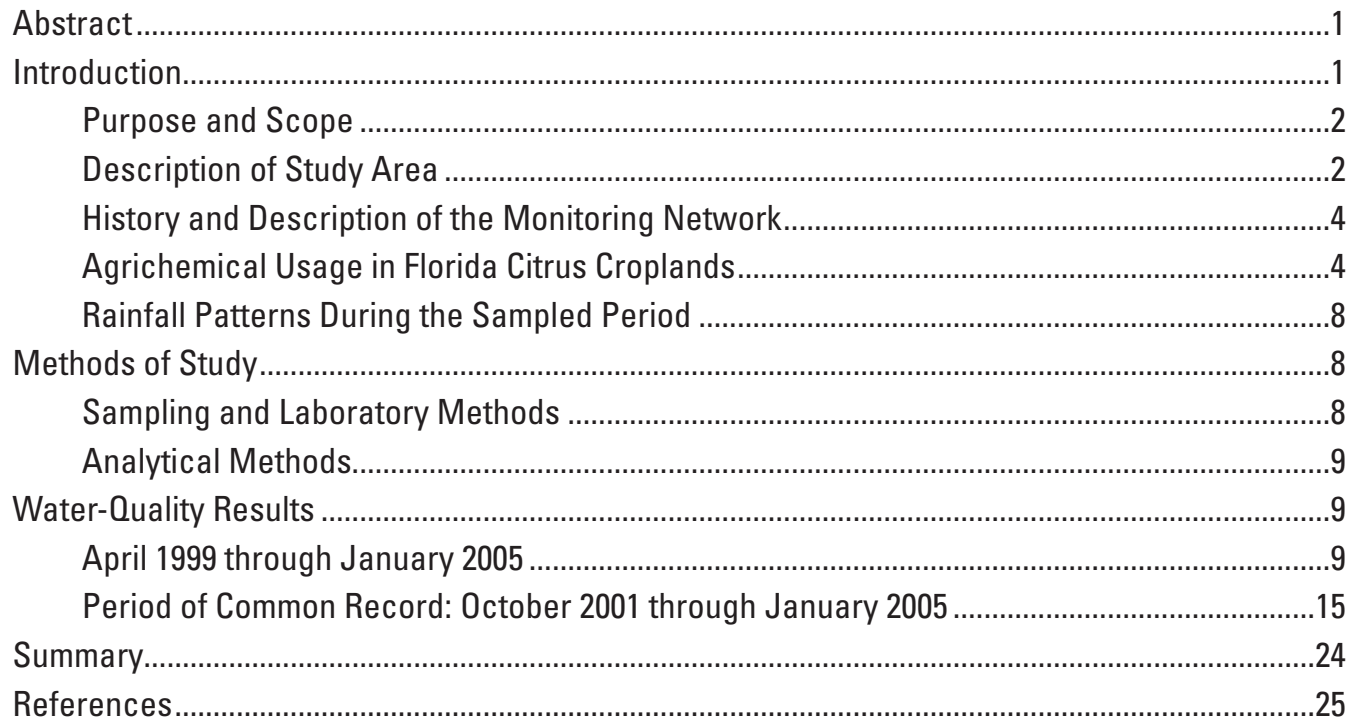

\section{Figures}

1. Locations of the Lake Wales Ridge Monitoring Network wells, citrus land use, and vulnerable soils in the study area ...........................................................................

2. Depth of well casing in the Lake Wales Ridge Network monitoring wells ........................5

3. Primary pesticides applied in Florida orange orchards in 2005, showing usage as the percent of total bearing acreage receiving applications .......................................6

4. Usage of selected pesticides applied in Florida orange orchards between

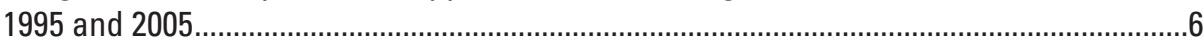

5. Statewide average application rates for selected pesticides in Florida orange orchards between 1997 and 2005 .

6. Statewide average application rates and number of applications for the fertilizers nitrogen, phosphate, and potash in Florida orange orchards in 1995, 1999, and 2003.

7. Monthly rainfall for the Lake Wales Ridge, January 1999 through January 2005 ..............8

8. Chemical degradation sources and pathways for analyzed triazine degradates ...........16

9. Median concentrations of aldicarb and aldicarb sulfone in samples from network wells, October 2001 through January 2005.................................................................18

10. Median concentrations of aldicarb sulfoxide and bromacil in samples from network wells, October 2001 through January 2005

11. Median concentrations of diuron and imidacloprid in samples from network wells, October 2001 through January 2005. 
12. Median concentrations of metalaxyl and nitrate (as $\mathrm{N}$ ) in samples from network wells, October 2001 through January 2005.

13. Median concentrations of norflurazon and demethyl norflurazon in samples from network wells, October 2001 through January 2005

14. Median concentrations of simazine and deisopropylatrazine (DIA) in samples from network wells, October 2001 through January 2005

15. Median concentrations of thiazopyr monoacid in samples from network wells, October 2001 through January 2005.

\section{Tables}

1. Nitrate and pesticide analytical methods performed by the Florida Department of Agriculture and Consumer Services Pesticide Laboratory for the Lake Wales Ridge Monitoring Network.

2. Laboratory reporting levels and detected pesticides and degradates analyzed in groundwater samples during April 1999 through January 2005

3. Laboratory reporting levels and detected triazine and phenylurea pesticides and degradates evaluated in groundwater from five wells sampled in July 2003.

4. Summary of time-series sampling-distribution statistics for pesticide and nitrate concentrations in groundwater samples, April 1999 through January 2005 .

5. Summary of pesticide and nitrate detections in samples from Lake Wales Ridge Monitoring Network wells during October 2001 through January 2005

Appendix Table (Excel file available for download at http://pubs.usgs.gov/of/2013/1271/appendix/ofr2013-1271_appendix1.xlsx)

1. Summary statistics by well for nitrate and detected pesticide concentrations for groundwater samples collected from April 1999 through January 2005. 


\section{Conversion Factors}

\begin{tabular}{|c|c|c|}
\hline Multiply & By & To obtain \\
\hline \multicolumn{3}{|c|}{ Length } \\
\hline inch (in.) & 2.54 & centimeter $(\mathrm{cm})$ \\
\hline inch (in.) & 25,400 & micrometer $(\mu \mathrm{m})$ \\
\hline foot $(\mathrm{ft})$ & 0.3048 & meter $(\mathrm{m})$ \\
\hline mile (mi) & 1.609 & kilometer $(\mathrm{km})$ \\
\hline \multicolumn{3}{|c|}{ Area } \\
\hline square mile $\left(\mathrm{mi}^{2}\right)$ & 2.5900 & square kilometer $\left(\mathrm{km}^{2}\right)$ \\
\hline \multicolumn{3}{|c|}{ Rate } \\
\hline pounds per acre (lbs/ac) & 1.12 & kilograms per hectare $(\mathrm{kg} / \mathrm{ha})$ \\
\hline \multicolumn{3}{|l|}{ SI to Inch/Pound } \\
\hline Multiply & By & To obtain \\
\hline \multicolumn{3}{|c|}{ Length } \\
\hline micrometer $(\mu \mathrm{m})$ & $3.937 \times 10^{-5}$ & inch (in.) \\
\hline \multicolumn{3}{|c|}{ Volume } \\
\hline liter $(\mathrm{L})$ & 33.82 & ounce, fluid (fl. oz) \\
\hline liter $(\mathrm{L})$ & 0.2642 & gallon (gal) \\
\hline \multicolumn{3}{|c|}{ Mass } \\
\hline milligram (mg) & $3.527396 \times 10^{-5}$ & ounce, avoirdupois (oz.) \\
\hline microgram $(\mu \mathrm{g})$ & $3.527396 \times 10^{-8}$ & ounce, avoirdupois (oz) \\
\hline
\end{tabular}

Vertical coordinate information is referenced to the North American Vertical Datum of 1988 (NAVD 88).

Horizontal coordinate information is referenced to the North American Datum of 1983 (NAD 83).

Altitude, as used in this report, refers to distance above the vertical datum.

Concentrations of chemical constituents in water are given either in milligrams per liter (mg/L) or micrograms per liter $(\mu \mathrm{g} / \mathrm{L})$. 


\section{Abbreviations}

DDA

DEA

DEHA

DIA

DIHA

FDACS

FDEP

GC

HA

HAL

HPLC

HS

ICP/MS

LC/MS

LRL

LWRM

MCL

$\mathrm{mg} / \mathrm{L}$

N

NAWQA

NPD

NTU

PTFE

SWFWMD

$\mu \mathrm{g} / \mathrm{L}$

USDA

USEPA

USGS

yr didealkylatrazine, or chlorodiamino-s-triazine (CAAT)

deethylatrazine, or 2-chloro-4-isopropylamino-6-amino-s-triazine (CIAT)

deethylhydroxyatrazine, or 2-hydroxy-4-isopropylamino-6-amino-s-triazine (OIAT)

deisopropylatrazine, or chloro-6-ethylamino-4-amino-s-triazine (CEAT), or deethylsimazine (DES)

deisopropylhydroxyatrazine, or 2-hydroxy-6-ethylamino-4-amino-s-triazine (OEAT)

Florida Department of Agriculture and Consumer Services

Florida Department of Environmental Protection

guidance concentration

2-hydroxyatrazine, or 2-hydroxy-4-isopropylamino-6-ethylamino-s-triazine (OIET)

lifetime health advisory

high-performance liquid chromatography

hydroxysimazine, or 2-hydroxy-4,6-diethylamino-s-triazine (OEET)

inductively coupled plasma-mass spectrometry

liquid chromatography-mass spectrometry

laboratory reporting level

Lake Wales Ridge Monitoring

maximum contaminant level

milligram per liter

nitrogen

National Water-Quality Assessment Program

nitrogen phosphorus detector

nephelometric turbidity unit

polytetrafluoroethylene, or "Teflon"

Southwest Florida Water Management District

microgram per liter

U.S. Department of Agriculture

U.S. Environmental Protection Agency

U.S. Geological Survey

year 


\section{Acknowledgments}

This report and the implementation and sampling of the Lake Wales Ridge Monitoring Network are the result of partnered contributions of the Florida Department of Agriculture and Consumer Services (FDACS), the Southwest Florida Water Management District (SWFWMD) and the U.S. Geological Survey. The SWFWMD field staff performed sample collection. Laboratory analyses were performed by the FDACS Pesticide Laboratory, the SWFWMD Water Quality Laboratory, and the U.S. Geological Survey Organic Geochemistry Research Laboratory. Ramona Turner, previously of the U.S. Geological Survey, assisted with data summaries and preparation of figures. Permission to access lands adjacent to monitoring wells was provided by a number of landowners to allow the field staff to perform sampling. 



\title{
Pesticides and Nitrate in Groundwater Underlying Citrus Croplands, Lake Wales Ridge, Central Florida, 1999-2005
}

\author{
By A.F. Choquette
}

\section{Abstract}

This report summarizes pesticide and nitrate (as nitrogen) results from quarterly sampling of 31 surficial-aquifer wells in the Lake Wales Ridge Monitoring Network during April 1999 through January 2005. The wells, located adjacent to citrus orchards and used for monitoring only, were generally screened (sampled) within 5 to 40 feet of the water table. Of the 44 citrus pesticides and pesticide degradates analyzed, 17 were detected in groundwater samples. Parent pesticides and degradates detected in quarterly groundwater samples, ordered by frequency of detection, included norflurazon, demethyl norflurazon, simazine, diuron, bromacil, aldicarb sulfone, aldicarb sulfoxide, deisopropylatrazine (DIA), imidacloprid, metalaxyl, thiazopyr monoacid, oxamyl, and aldicarb. Reconnaissance sampling of five Network wells yielded detections of four additional pesticide degradates (hydroxysimazine, didealkylatrazine, deisopropylhydroxyatrazine, and hydroxyatrazine). The highest median concentration values per well, based on samples collected during the 1999-2005 period ( $\mathrm{n}=14$ to 24 samples per well), included $3.05 \mu \mathrm{g} / \mathrm{L}$ (micrograms per liter) (simazine), $3.90 \mu \mathrm{g} / \mathrm{L}$ (diuron), $6.30 \mu \mathrm{g} / \mathrm{L}$ (aldicarb sulfone), $6.85 \mu \mathrm{g} / \mathrm{L}$ (aldicarb sulfoxide), $22.0 \mu \mathrm{g} / \mathrm{L}$ (demethyl norflurazon), $25.0 \mu \mathrm{g} / \mathrm{L}$ (norflurazon), $89 \mu \mathrm{g} / \mathrm{L}$ (bromacil), and $25.5 \mathrm{mg} / \mathrm{L}$ (milligrams per liter) (nitrate). Nitrate concentrations exceeded the $10 \mathrm{mg} / \mathrm{L}$ (as nitrogen) drinking water standard in one or more groundwater samples from 28 of the wells, and the median nitrate concentration among these wells was $14 \mathrm{mg} / \mathrm{L}$. Sampled groundwater pesticide concentrations exceeded Florida's health-guidance benchmarks for aldicarb sulfoxide and aldicarb sulfone (4 wells), the sum of aldicarb and its degradates ( 6 wells), simazine ( 2 wells), the sum of simazine and DIA ( 3 wells), diuron ( 2 wells), bromacil (1 well), and the sum of norflurazon and demethyl norflurazon (1 well). The magnitude of fluctuations in groundwater pesticide concentrations varied between wells and between pesticide compounds. Of the 10 pesticide compounds detected at sufficient frequency to assess temporal variability in quarterly sampling records, median values of the relative interquartile range (ratio of the interquartile range to the median) among wells typically ranged from about 100 to 150 percent. The relative interquartile range of pesticide concentrations at individual wells could be much higher, sometimes exceeding 200 to 500 percent. No distinct spatial patterns were apparent among median pesticide concentrations in sampled wells; nitrate concentrations tended to be greater in samples from wells in the northern part of the study area.

\section{Introduction}

The Lake Wales Ridge, a 700-square mile $\left(\mathrm{mi}^{2}\right)$ upland physiographic region in central Florida, is one of the primary citrus-production regions in Florida. In response to concerns regarding groundwater quality in this region, the Lake Wales Ridge Monitoring Network, hereafter referred to as the LWRM Network in this report, was established in April 1999 (Choquette and Sepulveda, 2000) and planned as a long term monitoring program. Network sampling has continued to present (2013) and is ongoing.

Previous summaries of LWRM Network sample results include assessment of 1990-2003 temporal trends in pesticide detections (Choquette and others, 2005; Gilliom and others, 2006) and a summary of 2009-2010 results for pesticides and inorganic chemicals including comparison between groundwater quality in citrus and non-citrus land-use areas (Choquette and others, 2012). Changes in agrichemical usage patterns and land use in this region potentially affecting groundwater quality include restrictions and (or) the prohibition of selected pesticides, discussed further in the section "Agrichemical usage in Florida citrus croplands"; the implementation of fertilizer best management practices (State of Florida, 2002b; Parsons and Boman, 2006); the onset and spread of citrus greening disease (National Academy of Sciences, 2010; Rogers and others, 2010; Rogers, 2011); and the conversion of citrus croplands to residential and commercial development. 


\section{Purpose and Scope}

The purpose of this report is to provide a summary of results of the LWRM Network water-quality samples collected from April 1999 through January 2005, along with information on concurrent pesticide usage and rainfall patterns. The summaries in this report include quarterly records of pesticide and nitrate concentrations in groundwater samples from 31 wells tapping the surficial aquifer (fig. 1) and results of reconnaissance sampling at 5 Network wells, which included analyses of several triazine pesticide degradates.

The water-quality summaries include maps and descriptive statistics (by well and by pesticide compound), determined using methods to adjust for censored ("less-than") values, and characterize the spatial and temporal variability of pesticide and nitrate concentrations in groundwater underlying citrus land use in the Lake Wales Ridge study area during the April 1999 through January 2005 period. A separate summary was performed for the period of common record, October 2001 through January 2005, when the network was implemented fully and all wells were sampled quarterly. Sampled concentrations also were compared to Florida's health-guidance benchmarks for groundwater.

This report documents water-quality conditions during the first 6 years of the LWRM Network monitoring program, planned as a long-term ( 20 or more years) program. The data summaries in this report also provide a basis for comparison with monitoring results for subsequent periods of record, to document, for example, potential water-quality responses to changes in land use and (or) agrichemical usage.

\section{Description of Study Area}

The Lake Wales Ridge, hereafter referred to as the Ridge in this report, is one of the most extensively cultivated and productive citrus areas in Florida and the Nation. Citrus covers about 24 percent (107,500 acres) of the study area (Southwest Florida Water Management District, 1998). Historically, citrus has been one of the top two agricultural crops in Florida, accounting for 68 percent of the Nation's citrus production, and generating more than 1.5 billion dollars of revenue annually (U.S. Department of Agriculture, 2006). The study area is located in Polk and Highlands Counties, which ranked first and third, respectively, statewide in 2005 total annual citrus production (National Agricultural Statistics Service, 2005).

Citrus cultivation in Florida occurs in two distinct physiographic environments: (1) the "ridge citrus," which occurs on the upland ridges of central Florida, including the study area, and is characterized by well-drained sandy soils; and (2) the "flatwoods citrus," which occurs predominantly in coastal and southern Florida and is characterized by poorly drained, flatwoods soils characterized by a high water table (Wilson and others, 2002). The "ridge citrus" areas comprise about 40 percent of Florida's total citrus acreage (Paramasivam and Sajwan, 2001).
Concentrations of most detected pesticides and pesticide degradates in groundwater from the LWRM Network wells have been among the highest observed in comparison to U.S. Geological Survey (USGS) groundwater networks sampled nationally (Choquette and others, 2005; Gilliom and others, 2006), indicating the vulnerability of groundwater in this region to leaching of agrichemicals. This vulnerability is related to climate, soils, and hydrogeology in the study area, coupled with widespread agricultural land use, the long growing season relative to many other areas of the United States, and the associated agrichemical applications. Additionally, the LWRM Network wells were located directly adjacent to active citrus orchards (commonly referred to as "groves") and groundwater samples were collected near the water table, increasing the opportunity to detect pesticides and to provide early warning of potential pesticide migration into deeper groundwater.

The ridge soils consist predominantly of sand, promoting rapid infiltration rates, and contain little organic matter to sorb or filter pesticide compounds. Most of the soils on the Ridge have been classified as vulnerable to agrichemical leaching (fig. 1; Wilson and others, 2002; Fishel, 2009). Among U.S. crop categories, citrus agriculture has been ranked as having the highest rate of herbicide use nationally and the third highest rate of insecticide use on the basis of active ingredient applied annually (Brandt, 1995; Barbash and Resek, 1996). Because of the mild climate and long growing season in Florida, the number and frequency of pesticide applications annually exceeds that in many other regions of the United States.

In recent years, Federal and State laws and regulations have been developed to reduce leaching of agricultural chemicals into groundwater and to protect drinking water sources (National Association of State Departments of Agriculture Research Foundation, 2000; Boman, 2002). Guidelines and restrictions on agrichemical usage have been developed specifically for the sandy soils on the Ridge to minimize the probability of leaching and protect water resources (State of Florida, 1995, 2002a, 2002b; Aerts and Nesheim, 2000). In 2002, fertilizer best management practices were adopted specifically for Ridge citrus (State of Florida, 2002b) to minimize leaching into groundwater.

The hydrogeology of the Ridge has been described in several reports (Duerr and others, 1988; Barr, 1992; Yobbi, 1996; Sacks and others, 1998; Choquette and Sepulveda, 2000). The subsurface of the Ridge consists of a mantled karst terrane where unconsolidated sands and clays overlie an irregular limestone surface. The Ridge is underlain by an unconfined surficial aquifer, intermediate confining unit/aquifer system, and the Upper Floridan aquifer. Within the study area, the surficial aquifer ranges from about 50 to 300 feet (ft) thick and predominantly consists of sands and clays that thicken from north to south. Summaries of groundwater quality of the surficial aquifer underlying areas of the Ridge appear in Sacks and others (1998), Spechler and Kroening (2007), Spechler (2010), and Florida Department of Environmental Protection (2012a and b). 


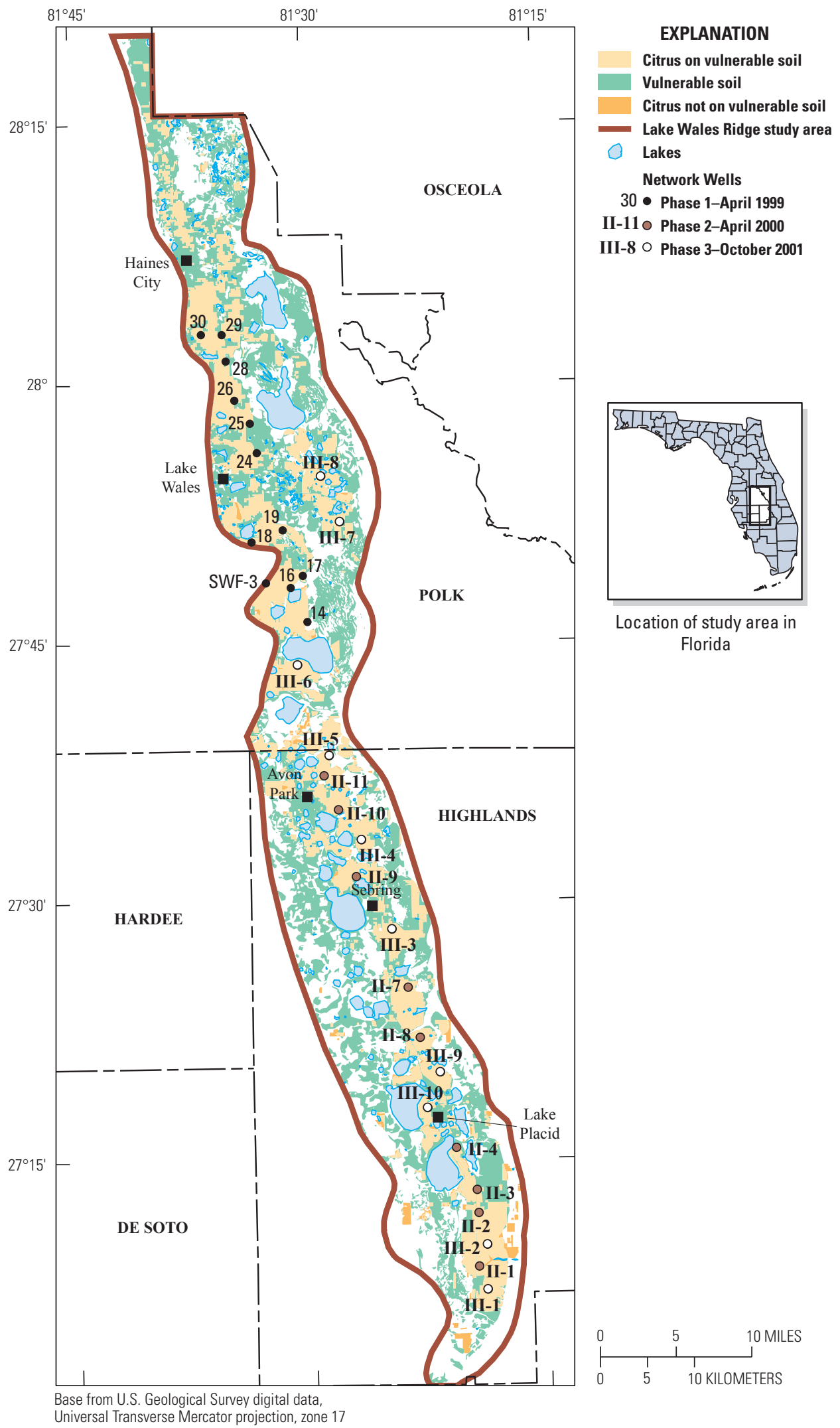

Figure 1. Locations of the Lake Wales Ridge Monitoring Network wells, citrus land use, and vulnerable soils in the study area. 
The surficial aquifer in the Ridge area is closely connected with more than 200 lakes, which cover about 10 percent of the Ridge (fig. 1) (Barcelo and others, 1990). These lakes both receive water from and discharge water to the aquifers underlying the Ridge (Sacks and others, 1998), and therefore, also are important for understanding the fate and transport of pesticides within the groundwater system. Vertical leakage from the surficial aquifer and from the lakes provides substantial amounts of water to the underlying intermediate aquifer system and the Upper Florida aquifer (Sepulveda, 2002).

A water-quality reconnaissance study of Ridge lakes (Choquette and Kroening, 2005 and 2009) indicated that both the suite of pesticides detected and their relative detection frequencies in lakes and groundwater correspond closely. However, the pesticide concentrations in the lakes typically were lower than those in groundwater, often by an order of magnitude or more, likely reflecting chemical degradation and dilution as the groundwater moves through the surficial aquifer and into the lakes, and the increased opportunity for biogeochemical degradation (including photolysis), adsorption, and dilution of pesticides within the lakes. The Ridge lake concentrations also were high relative to national surface-water pesticide concentrations reported by the USGS National WaterQuality Assessment (NAWQA) Program (Choquette and Kroening, 2009), consistent with the groundwater national comparison.

\section{History and Description of the Monitoring Network}

The LWRM Network was created to provide early warning of the occurrence of pesticides in the unconfined surficial aquifer, and information on the spatial and temporal variability of groundwater quality, including concentrations of agrichemicals and inorganic constituents. The design of the Network, planned as a long-term monitoring program and focused on vulnerable and shallow zones of the groundwater system, is described in detail in Choquette and Sepulveda (2000). The 1989-2010 sampling history and well construction characteristics appear in Choquette and others (2012).

As part of the LWRM Network monitoring program, although separate from this study, the Florida Department of Agriculture and Consumer Services (FDACS) established a series of responses if any water-quality constituents were detected in LWRM Network samples at levels approaching drinking-water health-guidance benchmarks (described in "Analytical Methods" section). The FDACS responses could involve initiating sampling of any nearby potable wells as a precautionary measure, notifying the U.S. Environmental Protection Agency (USEPA), adopting regulatory measures, and communicating with citrus growers and pesticide registrants (producers) to discuss actions to minimize groundwater contamination.

Quarterly sampling of the LWRM Network began with the 12 Phase I wells in April 1999, the addition of 9 Phase II wells in April 2000, and 10 Phase III wells in October 2001, after which all wells were sampled quarterly (fig. 1). Quarterly sampling typically commenced during January, April, July, and October, sometimes extending into the subsequent respective month. Prior to the establishment of the LWRM Network, 12 of the Phase I wells had been sampled intermittently during 1989 to April 1999 as part of the Florida
Department of Environmental Protection "Background" and "VISA citrus" monitoring networks (Ouellette and others, 1998; Silvanima and others, [n.d.]; Florida Department of Environmental Protection, 2012a, b) and for a USGS study (German, 1996).

Depth to the bottom of casing (coincident with the top of the well screen) in the LWRM Network wells ranges from 9 to $130 \mathrm{ft}$ (fig. 2). The well screens are $20 \mathrm{ft}$ long in 11 of the Phase I wells and are 10 to $11 \mathrm{ft}$ long in the remaining 20 wells. Water-table depth ranged from about 4 to $103 \mathrm{ft}$ (median $38 \mathrm{ft}$ ) among the sampled wells, and sampling depth (depth of the top of the well screen below the water table) ranged from $0 \mathrm{ft}$ (top of screen at or above the water table) to about $38 \mathrm{ft}$. It should be noted that water-quality results from the monitoring wells may differ from water quality in potable wells in the study area due to restrictions on agrichemical applications near potable wells ${ }^{1}$ and differences in potable-well construction (for example, depth of well, length and depth of well screens or intake zones, pumping rates, and area of groundwater contribution).

\section{Agrichemical Usage in Florida Citrus Croplands}

About 60 million pounds (active ingredient) of pesticides were applied in Florida's citrus croplands in 2001 (U.S. Department of Agriculture, 2002). Information on pesticide usage near the Network wells on the Ridge is not readily available and records of usage are not required to be regularly reported by growers; however, the U.S. Department of Agriculture (USDA) provides estimates of average annual pesticide usage by state and crop type (U.S. Department of Agriculture, 1996 to 2006), including the crop type "oranges," which represented more than 90 percent of citrus in Polk and Highlands Counties (Shahane, 2003). The USDA estimates represent statewide averages; local usage may differ from these values. Estimates of pesticide usage in Florida orange orchards in 2005 are shown in figure 3.

Excluding petroleum distillate, 2002-2003 pesticide usage (pounds of active ingredient per year) in orange orchards included herbicides ( 50 percent of total), insecticides ( 29 percent), and fungicides ( 21 percent). Herbicides, insecticides, and fungicides were applied in 95, 91, and 61 percent, respectively, of Florida orange orchards in 2002-2003 (U.S. Department of Agriculture, 2004). Based on crop acreage, the most widely applied pesticides during 1995 through 2005 included petroleum distillate (mineral oil), primarily used as an insecticide, and glyphosate, an herbicide - both of which typically were applied in more than 70 percent of citrus croplands (fig. 4). During this period there was an apparent decline in the usage of diuron, abamectin, and bromacil, and an increase in usage of 2,4-D (fig. 4). Rates of application of petroleum distillate (70 to 92 pounds per acre per year (lbs/ac/yr) were much higher than that for other pesticides ( 1 to $4 \mathrm{lbs} / \mathrm{ac} / \mathrm{yr}$ ) (fig. 5).

${ }^{1}$ Florida statutes specify minimum depths and (or) separation distances for potable wells in proximity to aldicarb application areas (State of Florida, 1997 and 2002a). 


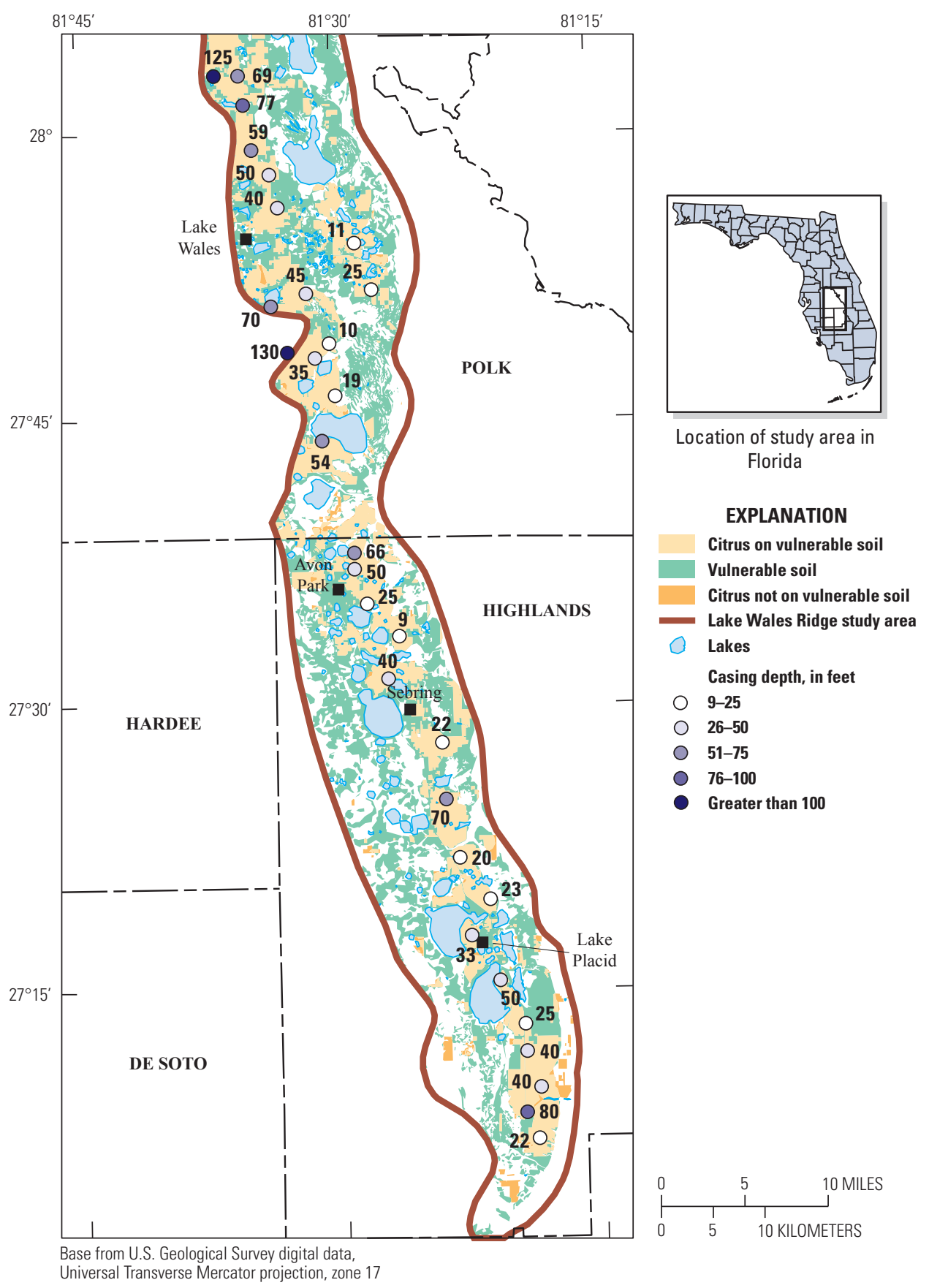

Figure 2. Depth of well casing in the Lake Wales Ridge Network monitoring wells. The casing depth coincides with the top of the well screen. 


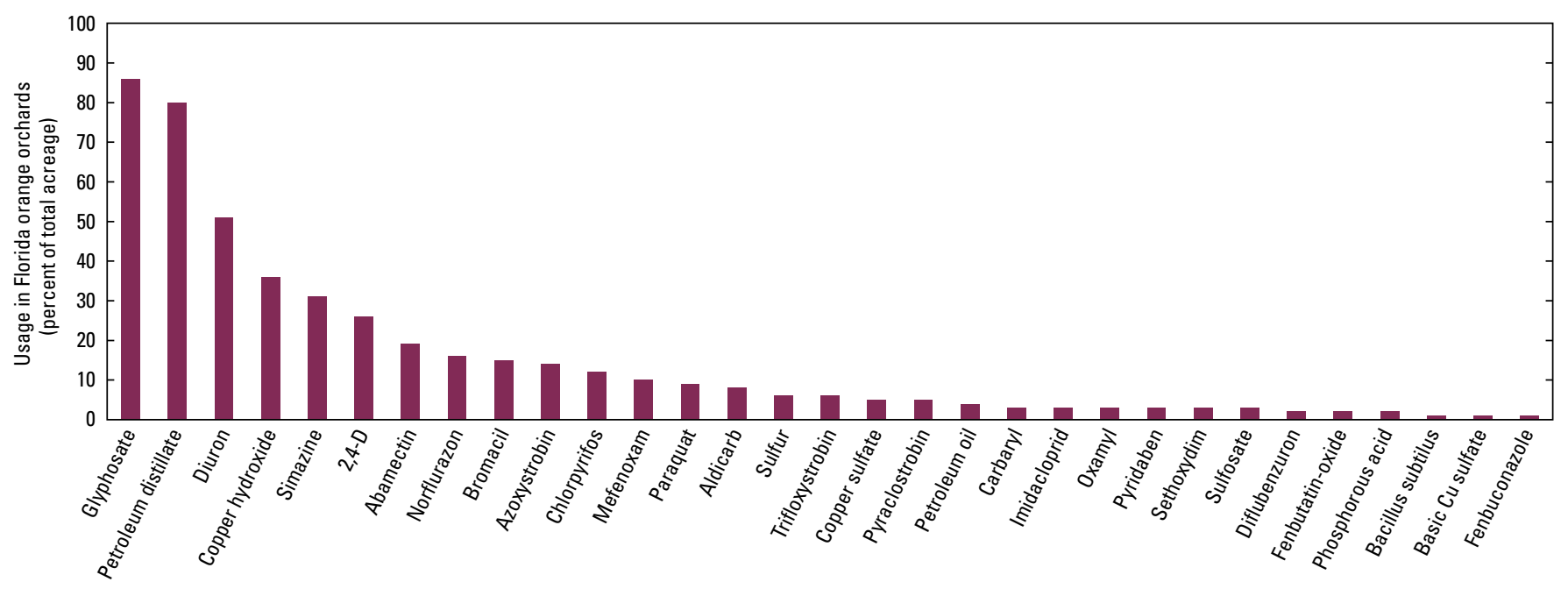

Figure 3. Primary pesticides applied in Florida orange orchards in 2005, showing usage as the percent of total bearing acreage receiving applications (U.S. Department of Agriculture, 2006).

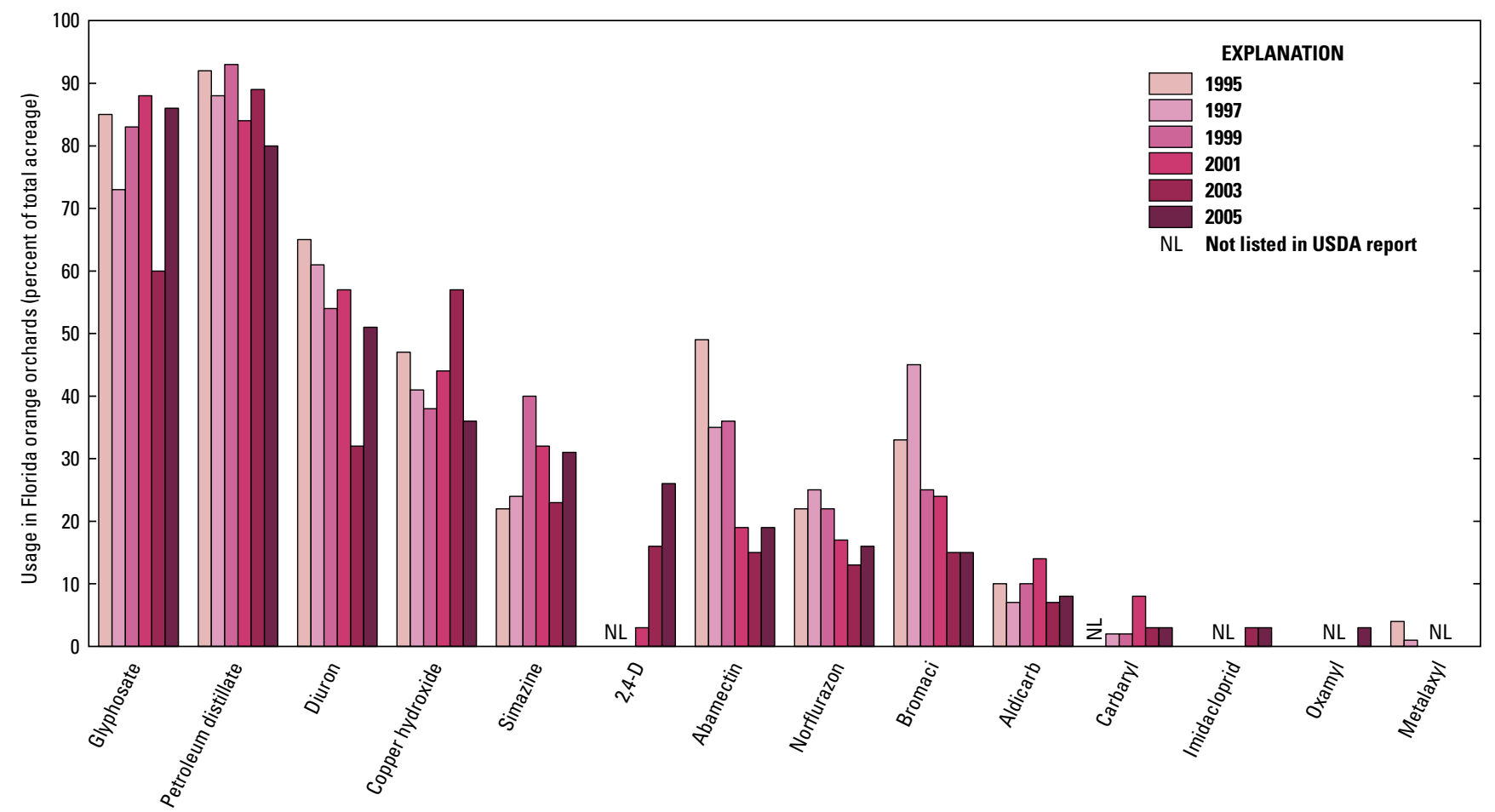

Figure 4. Usage of selected pesticides applied in Florida orange orchards between 1995 and 2005. Usage refers to the percent of total bearing acreage receiving applications (U.S. Department of Agriculture (USDA), 1996-2006). 


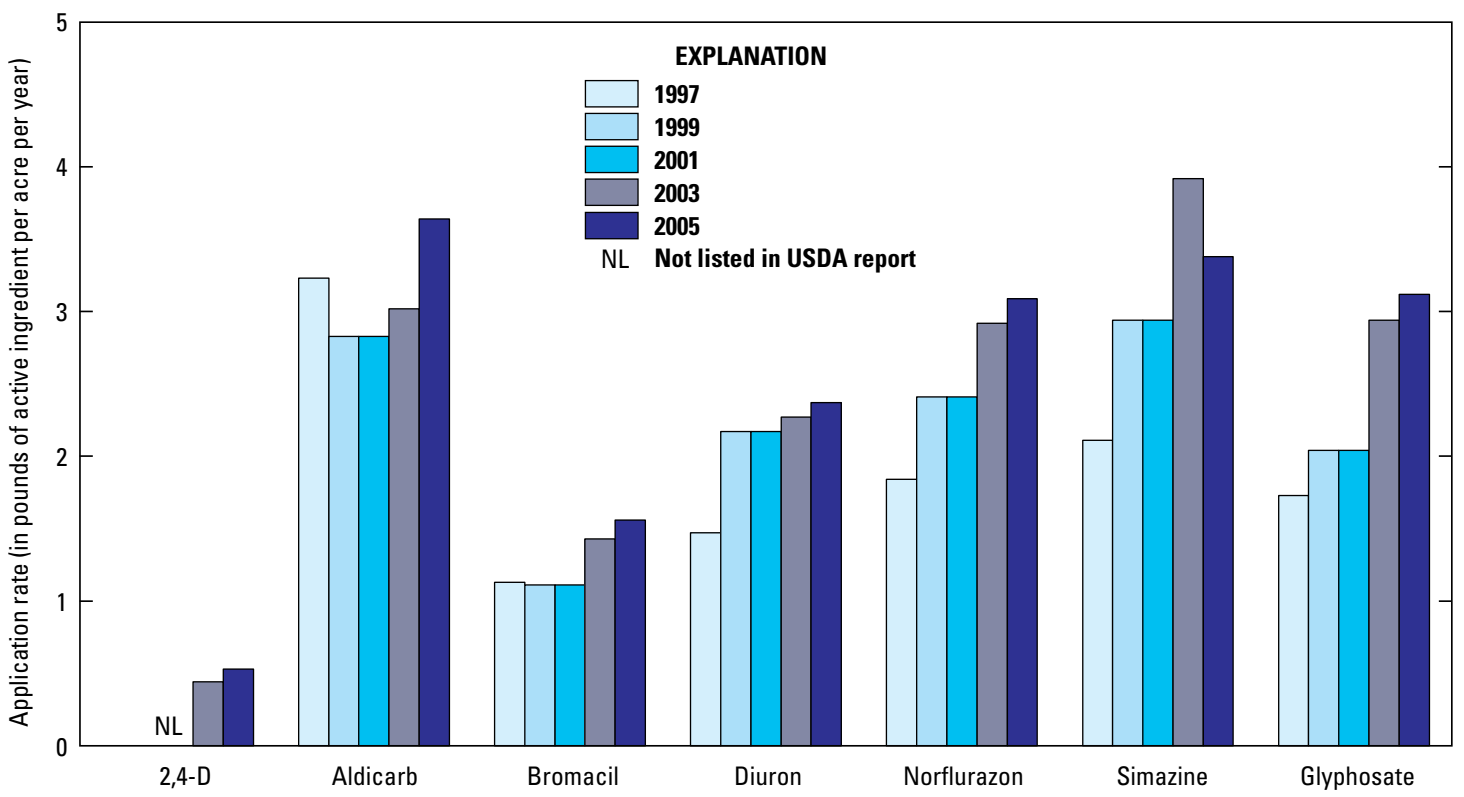

Figure 5. Statewide average application rates for selected pesticides in Florida orange orchards between 1997 and 2005 (U.S. Department of Agriculture (USDA), 1998-2006).

Usage of several citrus pesticides, including 1,2-dibromoethane, bromacil, fenamiphos, and aldicarb, has been either restricted or prohibited in the vulnerable soils of the Ridge (State of Florida, 1995, 2002a; Aerts and Nesheim, 2000). Bromacil was prohibited from use in most Ridge citrus areas in December 1994 (State of Florida, 1995; Fishel, 2009), and it has subsequently been replaced by other herbicides including norflurazon and glyphosate. In Florida, aldicarb is a restricted-use pesticide with limits on the amounts, timing, and locations of applications ${ }^{2}$ (State of Florida, 2002a). The USEPA announced a phased termination of aldicarb use on all crops nationally, beginning with citrus (United States Environmental Protection Agency, 2010). The registration of aldicarb for use on citrus was cancelled in August 2010 and use of aldicarb stocks on hand was required to be terminated in citrus croplands by December 31, 2011.

Estimates of statewide average pesticide application rates (active ingredient/acre/year) indicated a 60 to 80 percent increase between 1997 and 2005 for diuron, norflurazon, simazine, and glyphosate, and the amount of increases exceeded $1 \mathrm{lb} / \mathrm{ac} / \mathrm{yr}$ for several of these pesticides (fig. 5). The 1997 application rate for the herbicide simazine was higher for citrus in Florida than for any other crop nationally, and was twice that used in California citrus (Gianessi and Silvers, 2000). Between 1997 and 2001, the herbicides norflurazon, diuron, and simazine were applied in orange orchards on the average about 1.5 times per year (U.S. Department of Agriculture, 2002). Norflurazon, diuron, and simazine generally are applied prior to weed germination (pre-emergent) during spring and (or) fall.

\footnotetext{
${ }^{2}$ In citrus groves on sandy soils, aldicarb use is limited to one application per year at a maximum rate of $5 \mathrm{lbs}$ active ingredient per acre, applications must occur between January 1st and April 30th, and its usage is prohibited near potable wells (State of Florida, 2002a).
}

Citrus cultivation on the Florida Ridge soils often requires fertilization with nitrogen, phosphorus (as phosphate), potassium (as potash), and magnesium, along with lime (calcium carbonate) amendments to maintain a moderately acidic soil (Stauffer, 1991). Annual average application rates for fertilizers in Florida orange orchards from 1995 to 2003 (fig. 6) were about 180 to $215 \mathrm{lbs} / \mathrm{ac}$ nitrogen, 185 to $213 \mathrm{lbs} / \mathrm{ac}$ potash, and 30 to $73 \mathrm{lbs} / \mathrm{ac}$ phosphate applied to 94, 94, and 71 percent of orange orchards, respectively, in 1999 (U.S. Department of Agriculture, 1996, 2000, and 2004). Nitrogen, phosphate, and potash fertilizers were applied to Florida orange orchards an average of 4.9 to 5.2 times per year during 1995, and 2.8 to 3.4 times per year during 2003 (fig. 6).

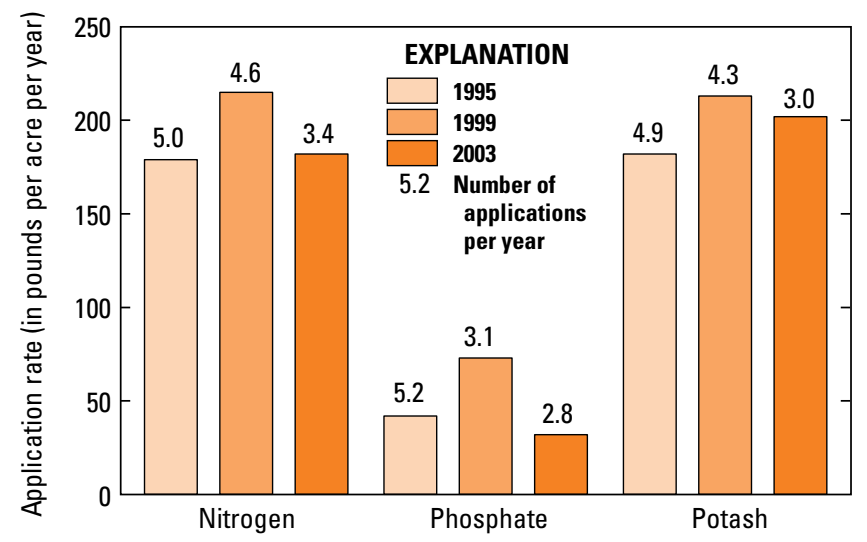

Figure 6. Statewide average application rates and number of applications for the fertilizers nitrogen, phosphate, and potash in Florida orange orchards in 1995, 1999, and 2003 (U.S. Department of Agriculture, 1996, 2000, and 2004). 


\section{Rainfall Patterns During the Sampled Period}

Annual rainfall on the Ridge ranged from 32.57 to 66.90 inches during the 1999 through 2005 period, based on the average rainfall determined using six climate-gaging stations distributed across the Lake Wales Ridge (National Oceanic and Atmospheric Administration, 1999-2005). Rainfall varies seasonally, and typically is greatest during June through September (fig. 7). Spatial variability of rainfall on the Ridge can be substantial, as a result of localized convective storms common during summer months. Variations in monthly totals between some of these climate stations during the 1999-2005 period exceeded 5 to 10 inches during some of the summer months.

The 1999 through 2005 period exhibited some of the wettest and driest years during the 1932-2005 record at Archbold Biological Research Station (Choquette and others, 2012). Additionally, in late summer and fall 2004, three major hurricanes passed directly across the Ridge, with associated intense wind and rainfall, and substantial damage to citrus foliage, fruit, and trees (Bossak, 2004; Albrigo and others, 2005).

\section{Methods of Study}

Sampling methods adhered to stringent protocols for trace (parts per billion) constituents, and laboratory analyses for pesticides and pesticide degradate concentrations were performed using high-performance liquid chromatography/mass spectrometry, and gas and ion chromatography. Analytical methods used to generate summary statistics included adjustments for censored concentrations and nonparametric methods. Florida's human health benchmarks for groundwater (described in "Analytical Methods" section) were used to identify constituents that may warrant further evaluation. All nitrate values in this report refer to measurement units "as N."

\section{Sampling and Laboratory Methods}

Groundwater samples were collected and processed according to the Florida Department of Environmental Protection (FDEP) and the Southwest Florida Water Management District (SWFWMD) groundwater sampling protocols (Morse, 1999; Florida Department of Environmental Protection, 2002; Southwest Florida Water Management District, 20066). Field protocols included a minimum purge of three well volumes, stabilization of $\mathrm{pH}$, specific conductance, temperature, and dissolved oxygen prior to sample collection, and turbidity of less than 10 nephelometric turbidity units (NTUs). The turbidity specification was established in April 2001. Samples collected prior to April 2000 were collected using a Teflon bailer; after this date, samples were collected using a Grunfos submersible pump and Teflon tubing. Pesticide samples analyzed for carbamates (aldicarb, aldicarb sulfone, aldicarb sulfoxide, methomyl, and oxamyl) were filtered in the laboratory using a 0.45 -micrometer $(\mu \mathrm{m})$ hydrophilic polytetrafluoroethylene (PTFE, or "Teflon") syringe filter (Teresa Rygiel, Florida Department of Agriculture and Consumer Services, written commun., Feb. 24, 2009). Quality control and assurance samples represented at least 25 percent of collected samples.

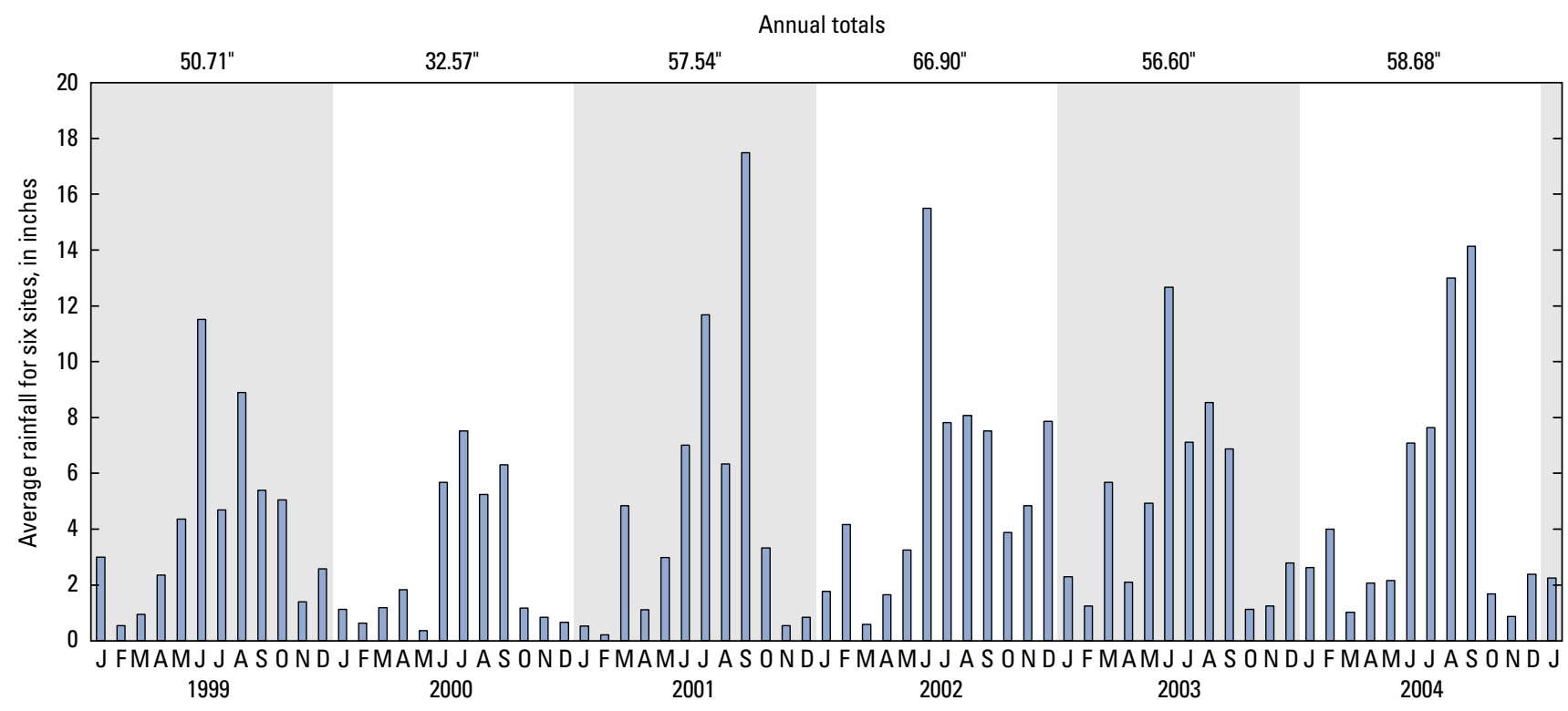

Figure 7. Monthly rainfall for the Lake Wales Ridge, January 1999 through January 2005. The monthly values are the average of six weather stations distributed across the Ridge (Archbold Biological Research Station, Avon Park 2W, Desoto City 8SW, Lake Alfred Experiment Station, Mountain Lake, Winter Haven; National Oceanic and Atmospheric Administration, 2010). 
A total of 30 pesticides and degradates were included as target analytes in routine quarterly sampling (table 1). Analyses of nitrate, pesticides, and pesticide degradates for the quarterly groundwater samples were performed by the FDACS Pesticide Laboratory. The pesticides and pesticide degradates were analyzed using gas chromatography with a nitrogen phosphorous detector (NPD), high-performance liquid chromatography (HPLC, utilizing both ultraviolet/visible (UV/VIS) spectroscopic detectors and post column derivatization), liquid chromatography/mass spectrometry (LC/MS) and ion chromatography, and included both standard USEPA methods and FDACS custom methods for selected compounds (Brock and Rygiel, 2003; Page and Stepp, 2003; Rygiel, 2003). Concentrations of organic compounds in spiked samples analyzed by the FDACS Pesticide Laboratory during the 1999 2005 period generally were within about 75 to 105 percent of expected concentration, with the exception of deisopropylatrazine, which yielded about 50 percent recovery.

Laboratory reporting levels for pesticides and degradates ranged from 0.025 to $16 \mu \mathrm{g} / \mathrm{L}$ (tables 2 and 3), and ranged from 0.1 and $0.5 \mu \mathrm{g} / \mathrm{L}$ for most of the routinely analyzed compounds (table 2). Reporting levels for several analytes were lowered during the April 1999 through January 2005 sampling period, and these changes are documented in Choquette and others (2012).

Reconnaissance sampling in July 2003 focused on selected triazine and phenylurea herbicides and their degradation products in groundwater at five of the LWRM Network wells (fig. 1, well numbers II-4, II-9, III-2, III-7, and III-10). The samples were analyzed for 5 of the target pesticides evaluated in quarterly sampling and 14 additional parent and degradate pesticides (table 3). These analyses were performed at the USGS Organic Geochemistry Laboratory using LC/MS methods described by Lee and others (2002).

\section{Analytical Methods}

Analyses of water-quality data included descriptive statistics to summarize results among Network wells and to summarize time-series records by well. Descriptive statistics for censored data were determined on the basis of the log-likelihood method (Helsel and Cohn, 1988; Helsel, 2005) using S-Plus Software (Insightful Corporation, 2001). A minimum of three sample detections above laboratory reporting levels were required to determine summary statistics using the log-likelihood method (Helsel, 2005), which also incorporated adjustments to account for multiple censoring levels. Nonparametric statistics were used in this report to avoid bias associated with parametric statistics, which can arise in the presence of skewed distributions (and outlying values), typical in water-quality records.

The pesticide and nitrate concentrations in the LWRM Network groundwater samples were compared to Florida groundwater human-health guidance concentrations (GCs). These benchmarks have been used by the FDACS, the FDEP, and other Florida agencies to identify water-quality constituents that might warrant further study and (or) additional sampling. Some of the GCs correspond to the Florida drinking-water regulations (maximum contaminant levels, or MCLs; State of Florida, 2012) and to the USEPA MCLs and lifetime health-advisory levels (HALs) (U.S.
Environmental Protection Agency, 2011). For pesticides for which MCLs or HALs have not been defined, the Florida GCs for groundwater correspond to Florida's Groundwater Cleanup Target Levels associated with State statutes (State of Florida, 2005; University of Florida, 2005). In addition, the Florida groundwater GCs for parent pesticide compounds have been used as the GCs for their respective degradates and (or) parent-degradate sums. Additional details regarding the Florida GCs and other humanhealth indices for the pesticide compounds detected in LWRM Network samples appear in Choquette and others (2012).

\section{Water-Quality Results}

The nitrate and pesticide results were summarized for two sampling periods: the 5.75-year period of record, April 1999 through January 2005 (1999-2005 period); and the 3.25-year "period of common record," October 2001 through January 2005 (2001-05 period), during which all of the LWRM Network wells were sampled. The period of common record is appropriate for regional comparisons among wells by water-quality constituent, avoiding possible bias from time-sampling error (for example, due to differences in water quality caused by variations in rainfall or groundwater recharge between sample years), and includes a uniform number of samples for each well.

\section{April 1999 through January 2005}

Of the 44 citrus pesticides and pesticide degradates analyzed, 8 parent compounds and 9 degradates were detected in groundwater samples from network wells between April 1999 and January 2005, including routine quarterly and reconnaissance sampling results (tables 2 and 3). Pesticides most often detected in groundwater samples during this period (table 4) included norflurazon and its degradate demethyl norflurazon (both detected in 87 percent of the wells), simazine (61 percent), diuron (52 percent), bromacil (52 percent), the aldicarb degradates aldicarb sulfone (39 percent) and aldicarb sulfoxide (32 percent), and deisopropylatrazine (35 percent) - a degradate of simazine and atrazine. Imidacloprid, metalaxyl, thiazopyr monoacid (thiazopyr degradate), oxamyl, and aldicarb were detected in 3 to 13 percent of the wells. The number of pesticides and degradates ${ }^{3}$ detected, by well, ranged from no detections at two wells to a maximum of nine detections at one well. About one-half of the wells (55 percent) yielded detections of five or more pesticides. Nitrate concentrations exceeded the $10 \mathrm{mg} / \mathrm{L}$ drinking water standard (USEPA MCL) in one or more groundwater samples from 90 percent of the wells. Concentrations of nitrate in the surficial aquifer underlying undeveloped lands in central Florida are low, typically less than 0.002 to $1.0 \mathrm{mg} / \mathrm{L}$ (Tihansky and Sacks, 1997; Adamski and German, 2004; Choquette and others, 2012).

${ }^{3}$ Excluding the simazine degradates, which were not evaluated in all of the Network wells. 
Table 1. Nitrate and pesticide analytical methods performed by the Florida Department of Agriculture and Consumer Services Pesticide Laboratory for the Lake Wales Ridge Monitoring Network.

[N, nitrogen; EPA, U.S. Environmental Protection Agency; ICP-MS, inductively coupled plasma mass spectrometry; FDACS, Florida Department of Agriculture and Consumer Services; HPLC, high-performance liquid chromatography; NPD, nitrogen phosphorus detector; LC, liquid chromatography; MS, mass spectrometry]

\begin{tabular}{|c|c|c|}
\hline $\begin{array}{c}\text { Constituent name } \\
\text { and fraction } \\
\text { (pesticide degradates in italics) }\end{array}$ & Analytical method & Method source or referenc \\
\hline Nitrate, dissolved (as N) & EPA 300.1 (ICP-MS) & Brock and Rygiel, 2003 \\
\hline Alachlor, whole water & $\begin{array}{l}\text { FDACS-NPD_HERBW, modified EPA } 600 \text { and } 1650 \\
\text { Series Method }\end{array}$ & $\begin{array}{l}\text { Teresa Rygiel, FDACS, written } \\
\text { commun., 4/1/2013 }\end{array}$ \\
\hline Aldicarb sulfone, dissolved & $\begin{array}{l}\text { FDACS-CarbamateW.MTH (HPLC/fluorescence), EPA } \\
531.1 \text { (ICP-MS) }\end{array}$ & Rygiel, 2003 \\
\hline Aldicarb sulfoxide, dissolved & $\begin{array}{l}\text { FDACS-CarbamateW.MTH (HPLC/fluorescence), EPA } \\
531.1 \text { (ICP-MS) }\end{array}$ & Rygiel, 2003 \\
\hline Aldicarb, dissolved & $\begin{array}{l}\text { FDACS-CarbamateW.MTH (HPLC/fluorescence), EPA } \\
531.1 \text { (ICP-MS) }\end{array}$ & Rygiel, 2003 \\
\hline Atrazine, whole water & $\begin{array}{l}\text { FDACS-NPD_HERBW, modified EPA } 600 \text { and } 1650 \\
\text { Series Method }\end{array}$ & $\begin{array}{l}\text { Teresa Rygiel, FDACS, written } \\
\text { commun., 4/1/2013 }\end{array}$ \\
\hline Bentazon, whole water & FDACS-Bentazon & Tola and Moody, 2007 \\
\hline Bromacil, whole water & FDACS-LC_HERBW & $\begin{array}{l}\text { Teresa Rygiel, FDACS, written } \\
\text { commun., 4/1/2013 }\end{array}$ \\
\hline Chlorpyrifos, whole water & $\begin{array}{l}\text { FDACS-NPD_HERBW, modified EPA } 600 \text { and } 1650 \\
\text { Series Method }\end{array}$ & $\begin{array}{l}\text { Teresa Rygiel, FDACS, written } \\
\text { commun., 4/1/2013 }\end{array}$ \\
\hline Deethylatrazine (DEA), whole water & $\begin{array}{l}\text { FDACS-NPD_HERBW, modified EPA } 600 \text { and } 1650 \\
\text { Series Method }\end{array}$ & $\begin{array}{l}\text { Teresa Rygiel, FDACS, written } \\
\text { commun., } 4 / 1 / 2013\end{array}$ \\
\hline Deisopropylatrazine (DIA), whole water & $\begin{array}{l}\text { FDACS-NPD_HERBW, modified EPA } 600 \text { and } 1650 \\
\text { Series Method }\end{array}$ & $\begin{array}{l}\text { Teresa Rygiel, FDACS, written } \\
\text { commun., 4/1/2013 }\end{array}$ \\
\hline Demethyl norflurazon, whole water & FDACS-LC_HERBW & $\begin{array}{l}\text { Teresa Rygiel, FDACS, written } \\
\text { commun., 4/1/2013 }\end{array}$ \\
\hline Dimethoate, whole water & $\begin{array}{l}\text { FDACS-NPD_HERBW, modified EPA } 600 \text { and } 1650 \\
\text { Series Method }\end{array}$ & $\begin{array}{l}\text { Teresa Rygiel, FDACS, written } \\
\text { commun., 4/1/2013 }\end{array}$ \\
\hline Diuron, whole water & FDACS-LC_HERBW & $\begin{array}{l}\text { Teresa Rygiel, FDACS, written } \\
\text { commun., 4/1/2013 }\end{array}$ \\
\hline Ethion, whole water & $\begin{array}{l}\text { FDACS-NPD_HERBW, modified EPA } 600 \text { and } 1650 \\
\text { Series Method }\end{array}$ & $\begin{array}{l}\text { Teresa Rygiel, FDACS, written } \\
\text { commun., 4/1/2013 }\end{array}$ \\
\hline Fenamiphos sulfone, whole water & FDACS-FNMPHOSW & $\begin{array}{l}\text { Teresa Rygiel, FDACS, written } \\
\text { commun., 4/1/2013 }\end{array}$ \\
\hline Fenamiphos sulfoxide, whole water & FDACS-FNMPHOSW & $\begin{array}{l}\text { Teresa Rygiel, FDACS, written } \\
\text { commun., } 4 / 1 / 2013\end{array}$ \\
\hline Fenamiphos, whole water & FDACS-FNMPHOSW & $\begin{array}{l}\text { Teresa Rygiel, FDACS, written } \\
\text { commun., } 4 / 1 / 2013\end{array}$ \\
\hline Imidacloprid, whole water & FDACS-LC_HERBW & $\begin{array}{l}\text { Teresa Rygiel, FDACS, written } \\
\text { commun., 4/1/2013 }\end{array}$ \\
\hline Iprodione, whole water & $\begin{array}{l}\text { FDACS-NPD_HERBW, modified EPA } 600 \text { and } 1650 \\
\text { Series Method }\end{array}$ & $\begin{array}{l}\text { Teresa Rygiel, FDACS, written } \\
\text { commun., } 4 / 1 / 2013\end{array}$ \\
\hline Malathion, whole water & $\begin{array}{l}\text { FDACS-NPD_HERBW, modified EPA } 600 \text { and } 1650 \\
\text { Series Method }\end{array}$ & $\begin{array}{l}\text { Teresa Rygiel, FDACS, written } \\
\text { commun., 4/1/2013 }\end{array}$ \\
\hline Metalaxyl, whole water & FDACS-LC_HERBW & $\begin{array}{l}\text { Teresa Rygiel, FDACS, written } \\
\text { commun., 4/1/2013 }\end{array}$ \\
\hline
\end{tabular}


Table 1. Nitrate and pesticide analytical methods performed by the Florida Department of Agriculture and Consumer Services Pesticide Laboratory for the Lake Wales Ridge Monitoring Network.-Continued

[N, nitrogen; EPA, U.S. Environmental Protection Agency; ICP-MS, inductively coupled plasma mass spectrometry; FDACS, Florida Department of Agriculture and Consumer Services; HPLC, high-performance liquid chromatography; NPD, nitrogen phosphorus detector; LC, liquid chromatography; MS, mass spectrometry]

\begin{tabular}{|c|c|c|}
\hline $\begin{array}{c}\text { Constituent name } \\
\text { and fraction } \\
\text { (pesticide degradates in italics) }\end{array}$ & Analytical method & Method source or reference \\
\hline Methomyl, dissolved & $\begin{array}{l}\text { FDACS-CarbamateW.MTH (HPLC/fluorescence), EPA } \\
531.1 \text { (ICP-MS) }\end{array}$ & Rygiel, 2003 \\
\hline Metolachlor, whole water & $\begin{array}{l}\text { FDACS-NPD_HERBW, modified EPA } 600 \text { and } 1650 \\
\text { Series Method }\end{array}$ & $\begin{array}{l}\text { Teresa Rygiel, FDACS, written } \\
\text { commun., 4/1/2013 }\end{array}$ \\
\hline Norflurazon, whole water & FDACS-LC_HERBW & $\begin{array}{l}\text { Teresa Rygiel, FDACS, written } \\
\text { commun., 4/1/2013 }\end{array}$ \\
\hline Oryzalin, whole water & FDACS-LC_HERBW & $\begin{array}{l}\text { Teresa Rygiel, FDACS, written } \\
\text { commun., 4/1/2013 }\end{array}$ \\
\hline Oxamyl, dissolved & $\begin{array}{l}\text { FDACS-CarbamateW.MTH (HPLC/fluorescence), EPA } \\
531.1 \text { (ICP-MS) }\end{array}$ & Rygiel, 2003 \\
\hline Thiazopyr monoacid, whole water & FDACS-ThiazopyrW.mth (HPLC-MS), ACIDHERB & $\begin{array}{l}\text { Page and Stepp, 2003; Tola and Moody, } \\
2007\end{array}$ \\
\hline Thiazopyr, whole water & FDACS-ThiazopyrW.mth (HPLC-MS), ACIDHERB & $\begin{array}{l}\text { Page and Stepp, 2003; Tola and Moody, } \\
2007\end{array}$ \\
\hline
\end{tabular}


Table 2. Laboratory reporting levels and detected pesticides and degradates analyzed in groundwater samples during April 1999 through January 2005.

[Pesticide degradates are shown in italics; analytes in bold were detected in groundwater samples; $\mu \mathrm{g} / \mathrm{L}$, micrograms per liter. Analyses were performed at the Florida Department of Agriculture and Consumer Services Pesticide Laboratory]

\begin{tabular}{lc}
\hline \multicolumn{1}{c}{ Analyte } & Reporting level ( $\boldsymbol{\mu g} / \mathbf{L})$ \\
\hline Alachlor & 2 \\
Aldicarb & $0.25,0.5,2,5$ \\
Aldicarb sulfone & $0.25,0.5,5$ \\
Aldicarb sulfoxide & $0.25,0.5,5$ \\
Atrazine & 0.2 \\
Bentazon & $0.04,1,2$ \\
Bromacil & $0.5,1$ \\
Chlorpyrifos & $0.2,0.4,0.5$ \\
Deethylatrazine (DEA) & 0.4 \\
Deisopropylatrazine (DIA; desmethyl simazine) & $0.4,0.6$ \\
Demethyl norflurazon & $0.5,1$ \\
Dimethoate & $0.2,1$ \\
Diuron & $0.5,2$ \\
Ethion & $0.2,2$ \\
Fenamiphos & $0.1,0.2$ \\
Fenamiphos sulfone & $0.1,0.2,0.4$ \\
Fenamiphos sulfoxide & $0.1,0.2,0.4$ \\
Imidacloprid & $0.5,1,3$ \\
Iprodione & $0.2,2,4,8$ \\
Malathion & 0.2 \\
Metalaxyl & 1,2 \\
Methomyl & $0.1,0.25,0.5,5$ \\
Metolachlor & 2 \\
Metribuzin & $0.4,0.1$ \\
Norflurazon & $0.5,16$ \\
Oxamyl & 0.1 \\
Oryzalin & \\
Thimazine & $0.5,1$ \\
\hline & \\
Thiazopyr monoacid & \\
\hline
\end{tabular}


Table 3. Laboratory reporting levels and detected triazine and phenylurea pesticides and degradates evaluated in groundwater from five wells sampled in July 2003.

[Pesticide degradates are shown in italics; analytes in bold were detected in groundwater samples; $\mu \mathrm{g} / \mathrm{L}$, micrograms per liter. Analyses were performed at the U.S. Geological Survey Organic Geochemistry Research laboratory, using methods described by Lee and others (2002)]

\begin{tabular}{ll}
\hline \multicolumn{1}{c}{ Analyte } & $\begin{array}{c}\text { Laboratory reporting levels } \\
(\boldsymbol{\mu} \mathrm{g} / \mathrm{L})\end{array}$ \\
\hline Atrazine & 0.025 \\
Bromacil & 0.05 \\
Cyanazine & 0.025 \\
Cyanazine amide & 0.025 \\
Cyanazine-acid & 0.025 \\
Deethylatrazine (DEA) & 0.025 \\
Deethylcyanazine & 0.025 \\
Deethylcyanazine acid & 0.025 \\
Deethylcyanazine amide & 0.025 \\
Demethyl fluometuron & 0.025 \\
Didealkylatrazine (DDA) & 0.025 \\
Deisopropylatrazine (DIA) & 0.025 \\
Deisopropylhydroxyatrazine (DIHA) & 0.025 \\
Diuron & 0.02 \\
Fluometuron & 0.025 \\
Hydroxyatrazine & 0.025 \\
Hydroxysimazine & 0.025 \\
Linuron & 0.025 \\
Propazine & 0.025 \\
Simazine & 0.025 \\
\hline
\end{tabular}




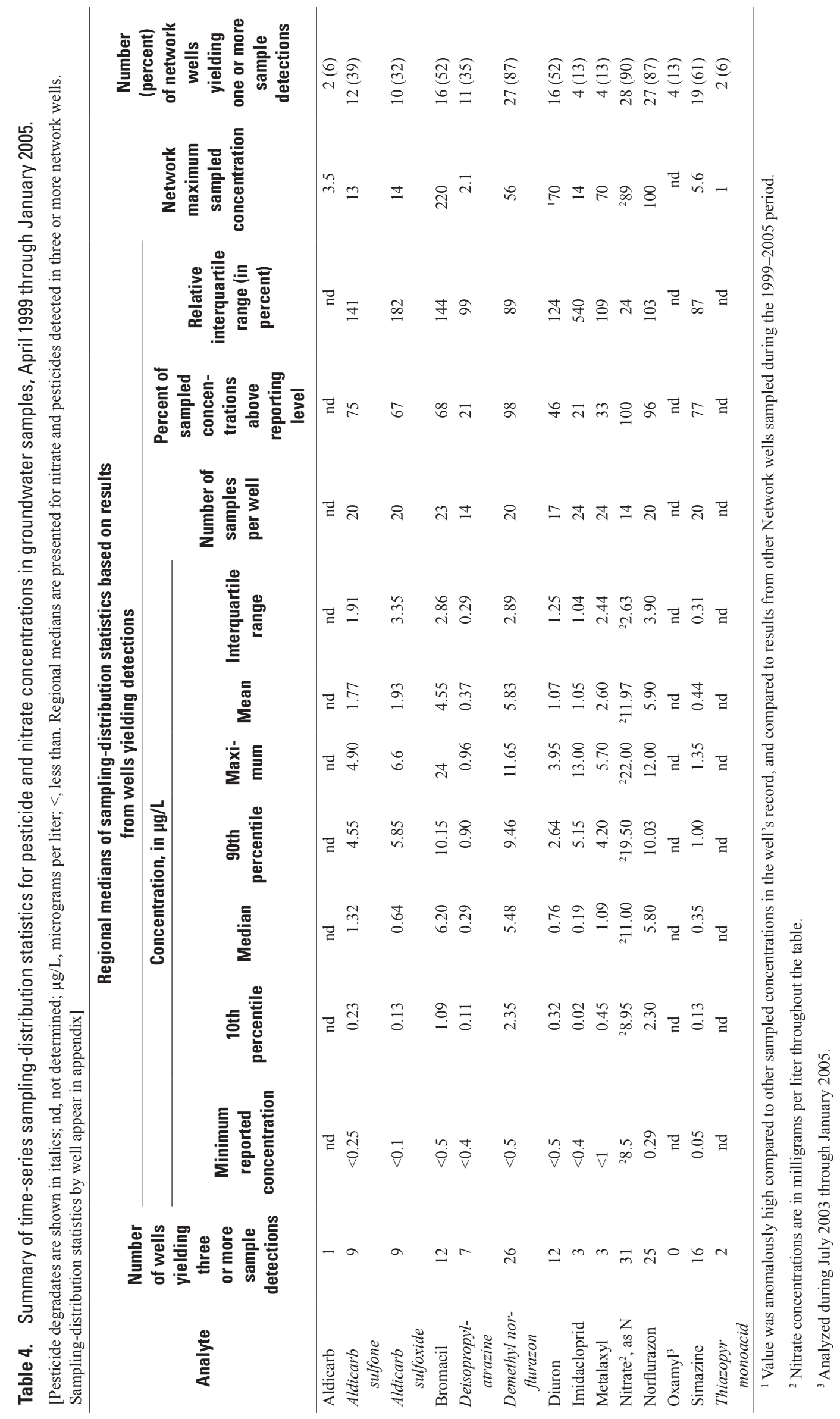


The triazine degradates hydroxysimazine (HS), deisopropylatrazine (DIA), didealkylatrazine (DDA), deisopropylhydroxyatrazine (DIHA), and hydroxyatrazine (HA) were detected in reconnaissance sampling focused on five of the LWRM Network wells that had previously yielded detections of simazine. These degradates include both first-order and second-order degradational products (fig. 8). Several of the triazine degradates are the products of multiple parent pesticides (Scribner and others, 1999), but simazine likely is the primary source of HS, DDA, DIA, and DIHA in groundwater underlying the Lake Wales Ridge citrus areas based on several factors (Choquette and Kroening, 2009), and simazine is the only triazine pesticide applied in Florida's citrus croplands.

The frequency of detection of specific pesticides in groundwater samples as a proportion of LWRM Network wells, and sampled lakes (Choquette and Kroening, 2009) on the Ridge, generally was greater than the areal extent of their estimated usage in orange orchards statewide (figs. 3 and 4). For example, norflurazon, although estimated to have been applied in only 13 to 24 percent of Florida orange orchards between 1995 and 2005 (fig. 4), was detected in water samples from nearly all Ridge wells and lakes sampled during 1999 through 2004 in regions of citrus land use (Choquette and others, 2003 and 2005).

The more widespread occurrence of detected pesticide compounds in the Ridge groundwater system in comparison to their estimated usage could result from a number of factors including effects of advection and dispersion as groundwater moves through the subsurface (Focazio and others, 2002), year-to-year rotation of different chemicals resulting in broader areal coverage over a number of years, and (or) regional usage patterns on Lake Wales Ridge that differ from the statewide averages. Aldicarb detections in groundwater samples were less widespread than the usage estimates indicate; however, the relatively rapid breakdown of aldicarb and the persistence of its degradates (Jones and others, 1987; Hornsby and others, 1990) result in the more frequent detections of the aldicarb degradates in groundwater samples. The variations in the chemical properties among these detected pesticides in relation to their presence in Ridge lakes and groundwater are further discussed in Choquette and Kroening (2009).

To examine temporal variability in concentrations at fixed locations, summary statistics were determined for time-series results of sampled water-quality concentrations by well (appendix). These statistics were calculated for wells that yielded samples with one or more detections of targeted pesticides and nitrate, and median values among wells were calculated (table 4) if at least three wells yielded detections in three or more samples. The highest median concentrations per well, based on samples collected during the 1999-2005 period ( $\mathrm{n}=14$ to 24 samples), were $25.5 \mathrm{mg} / \mathrm{L}$, nitrate; $89 \mu \mathrm{g} / \mathrm{L}$, bromacil; $25.0 \mu \mathrm{g} / \mathrm{L}$, norflurazon; $22.0 \mu \mathrm{g} / \mathrm{L}$, demethyl norflurazon; $6.85 \mu \mathrm{g} / \mathrm{L}$, aldicarb sulfoxide; $6.30 \mu \mathrm{g} / \mathrm{L}$, aldicarb sulfone; $3.90 \mu \mathrm{g} / \mathrm{L}$, diuron; $3.05 \mu \mathrm{g} / \mathrm{L}$, simazine; $2.55 \mu \mathrm{g} / \mathrm{L}$, imidacloprid; $2.23 \mu \mathrm{g} / \mathrm{L}$, metalaxyl; $0.54 \mu \mathrm{g} / \mathrm{L}$, DIA; and $0.22 \mu \mathrm{g} / \mathrm{L}$, thiazopyr monoacid (appendix).

Relatively large temporal fluctuations in pesticide concentrations occurred between quarterly samples at a given well, as indicated by the values for the relative interquartile range (table 4). The relative interquartile range of the timeseries records of sampled concentrations by well ranged from 87 to 540 percent among the 10 pesticide compounds evaluated, with highest temporal variability occurring in imidacloprid, aldicarb sulfoxide, aldicarb sulfone, bromacil, and diuron concentrations. The median relative interquartile range of sampled nitrate concentrations by well was 24 percent, considerably lower than the pesticide compounds.

During the April 1999 through January 2005 period, Florida human-health GCs for groundwater were exceeded in sampled concentrations including seven of the analyzed pesticides and degradates and (or) their parent-degradate sums. GC exceedances occurred for aldicarb sulfone and sulfoxide (4 wells, exceedance frequency ranging from 4 to 50 percent of the samples per well), the sum of aldicarb and its degradates ( 6 wells, 5 to 79 percent of samples per well), simazine ( 2 wells, 10 to 35 percent of samples per well), the sum of simazine and DIA ( 3 wells, 7 to 35 percent of samples per well), diuron ( 2 wells, 4 to 7 percent of samples per well), and bromacil (1 well, 65 percent of samples). Concentrations exceeded $0.5 \mathrm{GC}$ for an additional 3 pesticide compounds and (or) parent-degradate sums, including aldicarb (1 well), DIA (1 well), and the sum of norflurazon and demethyl norflurazon (1 well). The GC for norflurazon and its degradate was reduced from 280 to $105 \mu \mathrm{g} / \mathrm{L}$ during 2012. Applying the $105 \mu \mathrm{g} / \mathrm{L} \mathrm{GC}$ to the 1999-2005 record, GC exceedances occurred for the sum of norflurazon and demethyl norflurazon (1 well, 7 percent of samples); the $0.5 \mathrm{GC}$ was exceeded for norflurazon ( 3 wells), demethyl norflurazon ( 2 wells), and the sum of norflurazon and demethyl norflurazon (6 wells).

Concentrations of the sum of aldicarb plus its degradates and the sum of simazine plus DIA fluctuated above and below their respective GCs, both in groundwater from shallow wells and from wells as deep as 40 to $55 \mathrm{ft}$. Nitrate concentrations exceeded the GC in 28 of the 31 wells, including wells as deep as $130 \mathrm{ft}$. An unusually elevated concentration of diuron $(70 \mu \mathrm{g} / \mathrm{L}$ ) occurred in one sample (well number III-1, appendix). This diuron concentration was anomalously high compared to other sampled concentrations in the well's record $(n=14)$, and compared to results from other Network wells during the 1999-2005 period.

\section{Period of Common Record: October 2001 through January 2005}

Summary statistics were calculated for pesticide and nitrate detections and concentrations in groundwater samples collected during the 2001-2005 period of common record (table 5). The pesticide compounds detected and the percent of wells yielding detections were similar between the 
1999-2005 and 2001-2005 sampled periods (tables 4 and 5, respectively). The 2001-2005 median concentration per well for pesticide compounds ranged from 0.04 (imidacloprid) to 87 (bromacil $^{4}$ ) $\mu \mathrm{g} / \mathrm{L}$. The median concentration for all wells yielding detections, by pesticide, was less than $0.87 \mu \mathrm{g} / \mathrm{L}$ for all of the targeted pesticides and degradates except norflurazon and demethyl norflurazon, with median values of 5.9 and $6.7 \mu \mathrm{g} / \mathrm{L}$, respectively. The 2001-2005 regional median nitrate concentration was $14 \mathrm{mg} / \mathrm{L}$ among the 26 wells that yielded samples exceeding the $10 \mathrm{mg} / \mathrm{L} \mathrm{MCL}$, and in these wells 7 to 100 percent (median $=79$ percent) of the sampled concentrations exceeded $10 \mathrm{mg} / \mathrm{L}$ (table 5 and appendix).

There often was consistency in the particular pesticides detected in individual wells over time, as indicated by the percent of samples per well yielding detections (table 5). Consistency in detection frequency per well, during the 2001-2005 period, based on median values (table 5), exceeded 50 percent of samples in the wells yielding detections for norflurazon, demethyl norflurazon, simazine, aldicarb sulfoxide and aldicarb sulfone, and thiazopyr monoacid.

${ }^{4}$ Only one of the Network wells yielded median bromacil concentrations that exceeded the health-guidance value of $70 \mu \mathrm{g} / \mathrm{L}$.
Spatial variability of the October 2001-throughJanuary 2005 median concentrations of detected pesticides is shown in figures 9 through 15). Neither pronounced nor consistent spatial patterns were apparent in the median pesticide concentrations; however, nitrate concentrations typically were greater in sampled wells in the northern part of the study area compared to the southern part (fig. 12B).

Pesticide concentrations in samples from the Highlands County wells appeared somewhat higher than from the Polk County wells for simazine, DIA, and the sum of norflurazon and its degradate. Sampled concentrations of bromacil and nitrate appeared to be somewhat higher in Polk County wells compared to the wells in Highlands County. Further evaluation would be necessary to confirm such differences, which in part could result from the typically shorter well screens close to the water table for the Highlands County wells. In addition, the longer-screened Polk County wells may tap a mixture of older groundwater, capturing the effects (higher concentrations) of agrichemical usage prior to the bromacil usage prohibition and prior to implementation of nitrate best management practices in ridge citrus areas during the late 1990s and early 2000s.

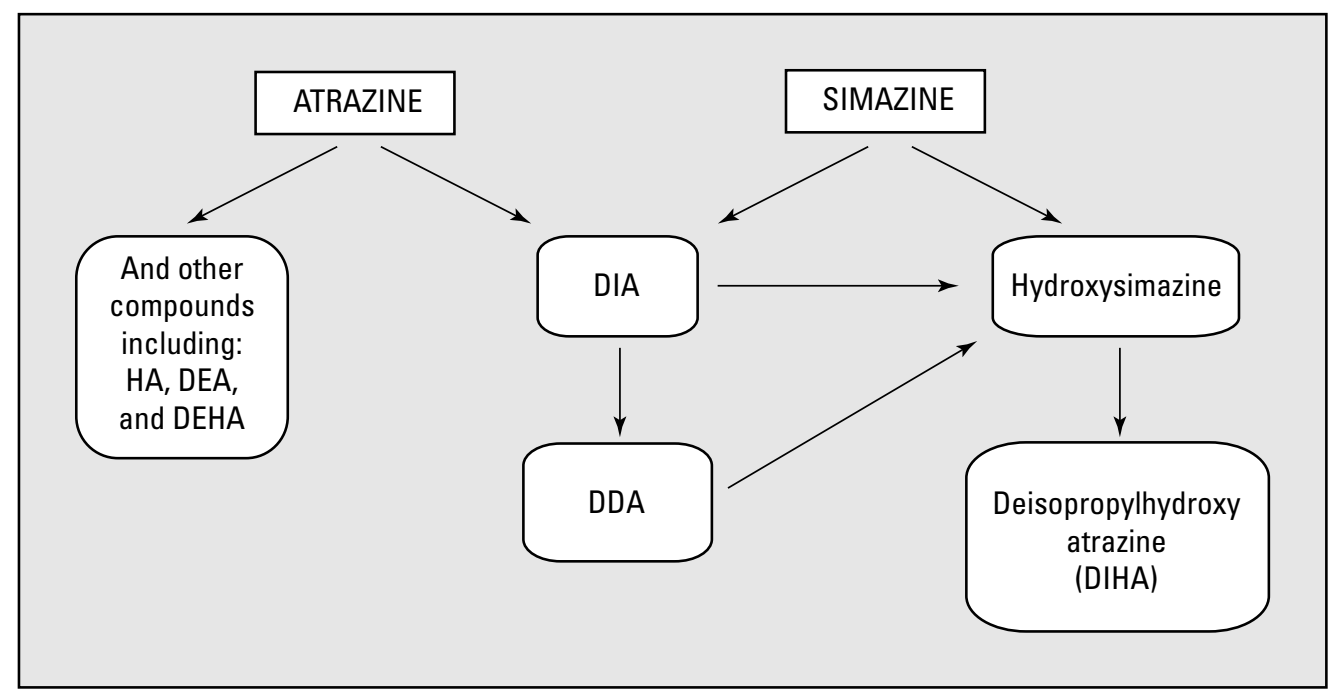

Figure 8. Chemical degradation sources and pathways for analyzed triazine degradates (Scribner and others, 1999; M.T. Meyer, U.S. Geological Survey, written commun., 2009). Atrazine is not registered for use, or applied, in Florida citrus orchards. Acronyms are defined under "Abbreviations." 


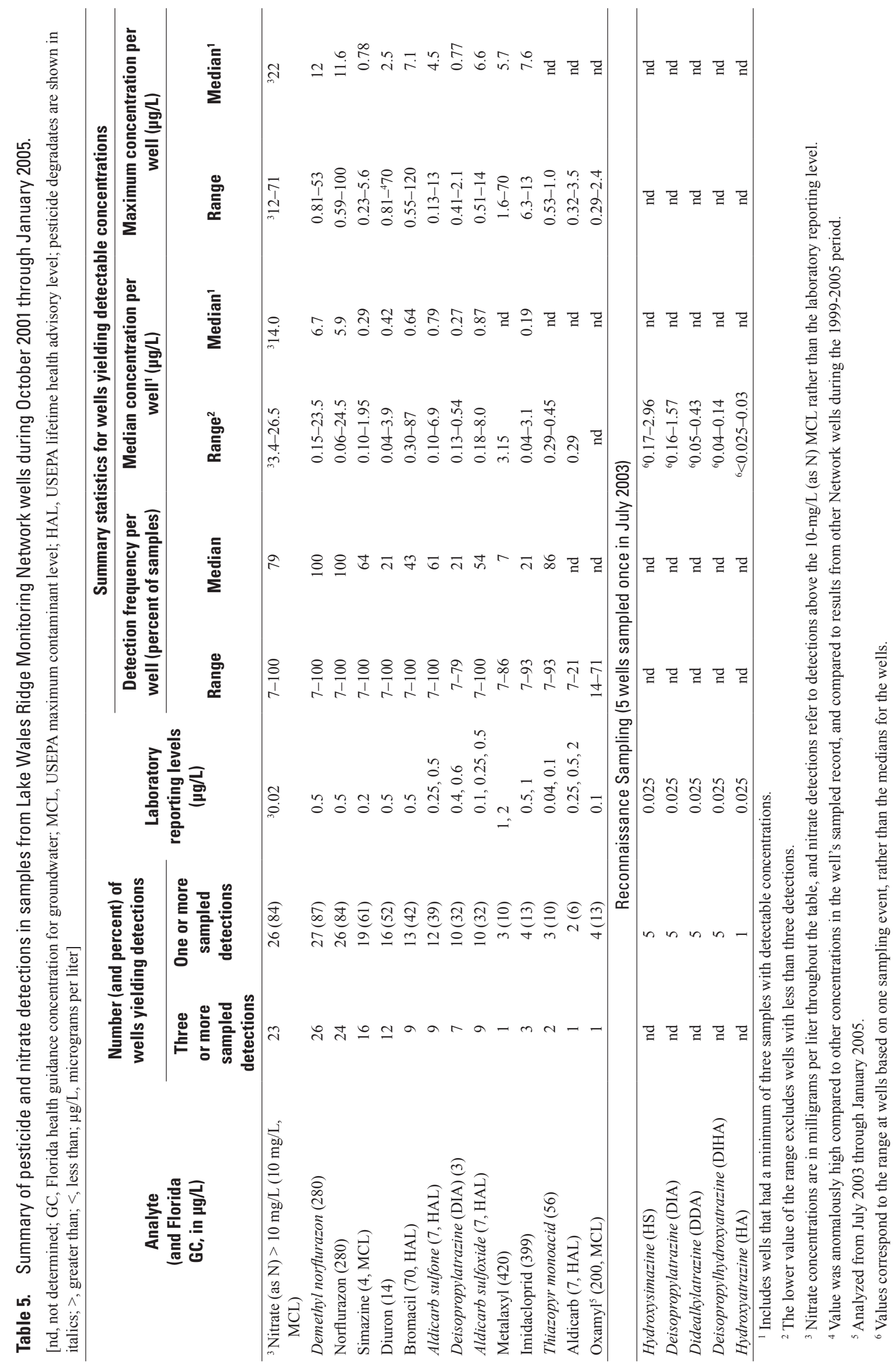




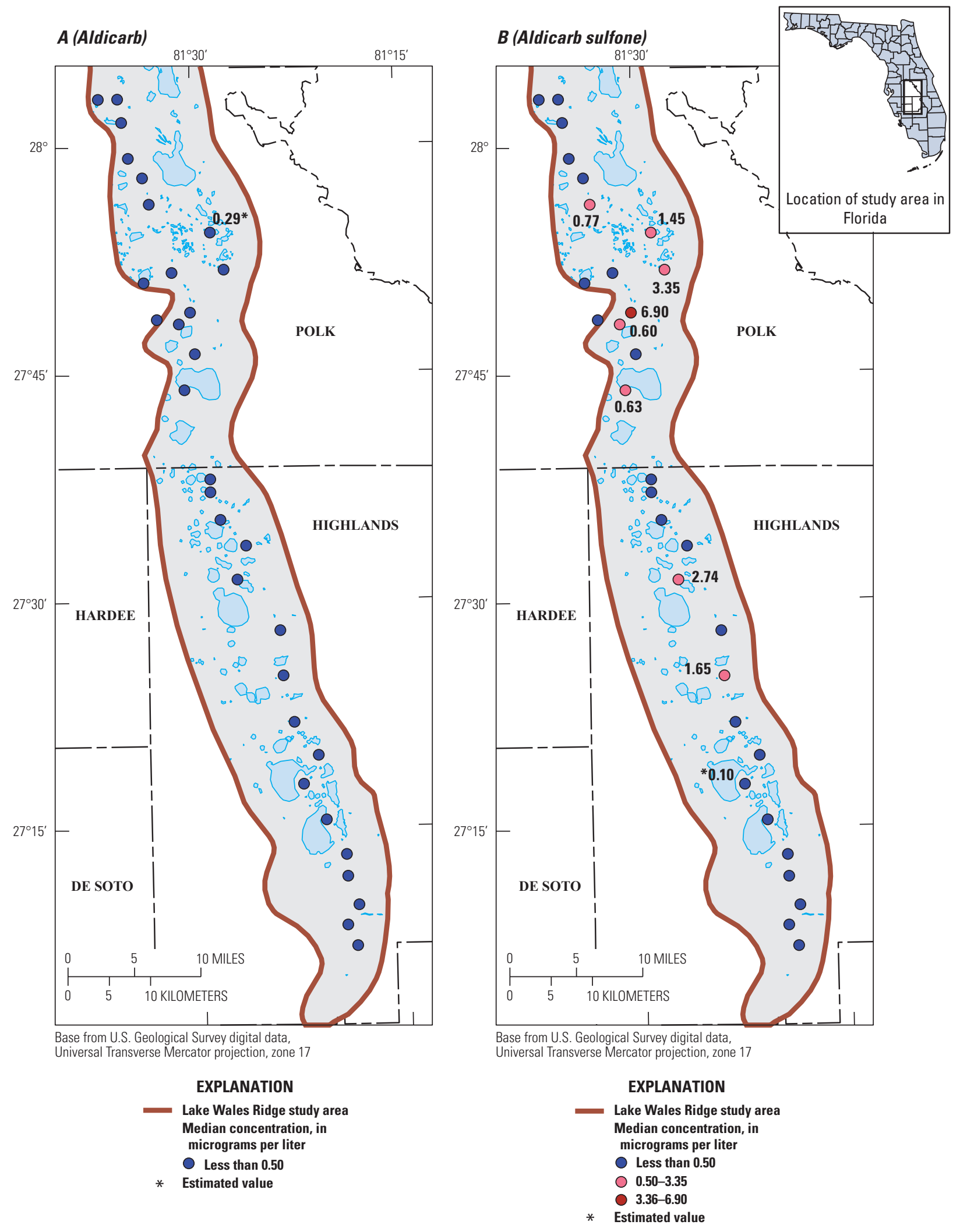

Figure 9. Median concentrations of $(A)$ aldicarb and $(B)$ aldicarb sulfone in samples from network wells, 0ctober 2001 through January 2005. "Estimated value" refers to medians, determined using the log-probability method, that were below the laboratory reporting level for the analyte. 


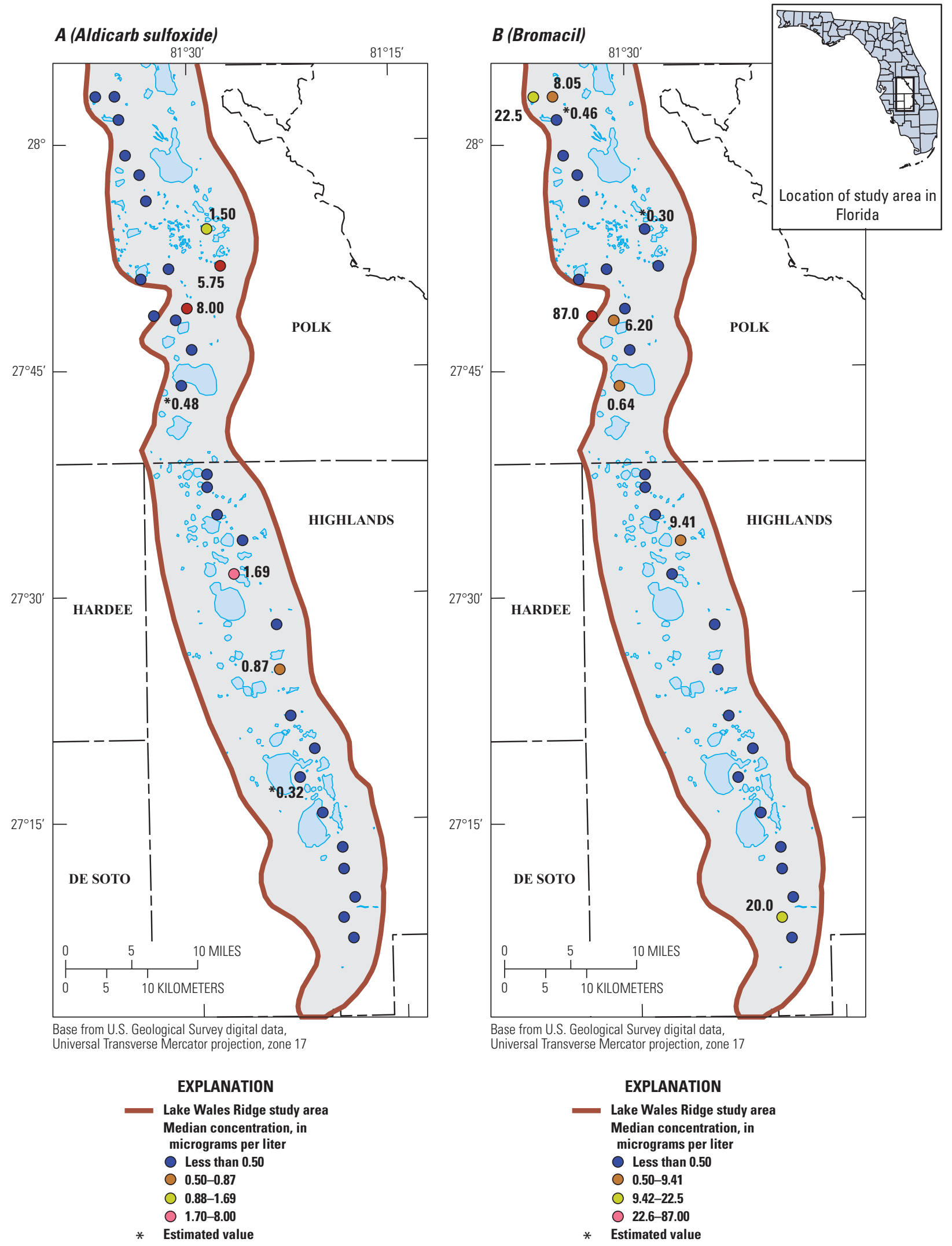

Figure 10. Median concentrations of $(A)$ aldicarb sulfoxide and $(B)$ bromacil in samples from network wells, October 2001 through January 2005. "Estimated value" refers to medians, determined using the log-probability method, that were below the laboratory reporting level for the analyte. 


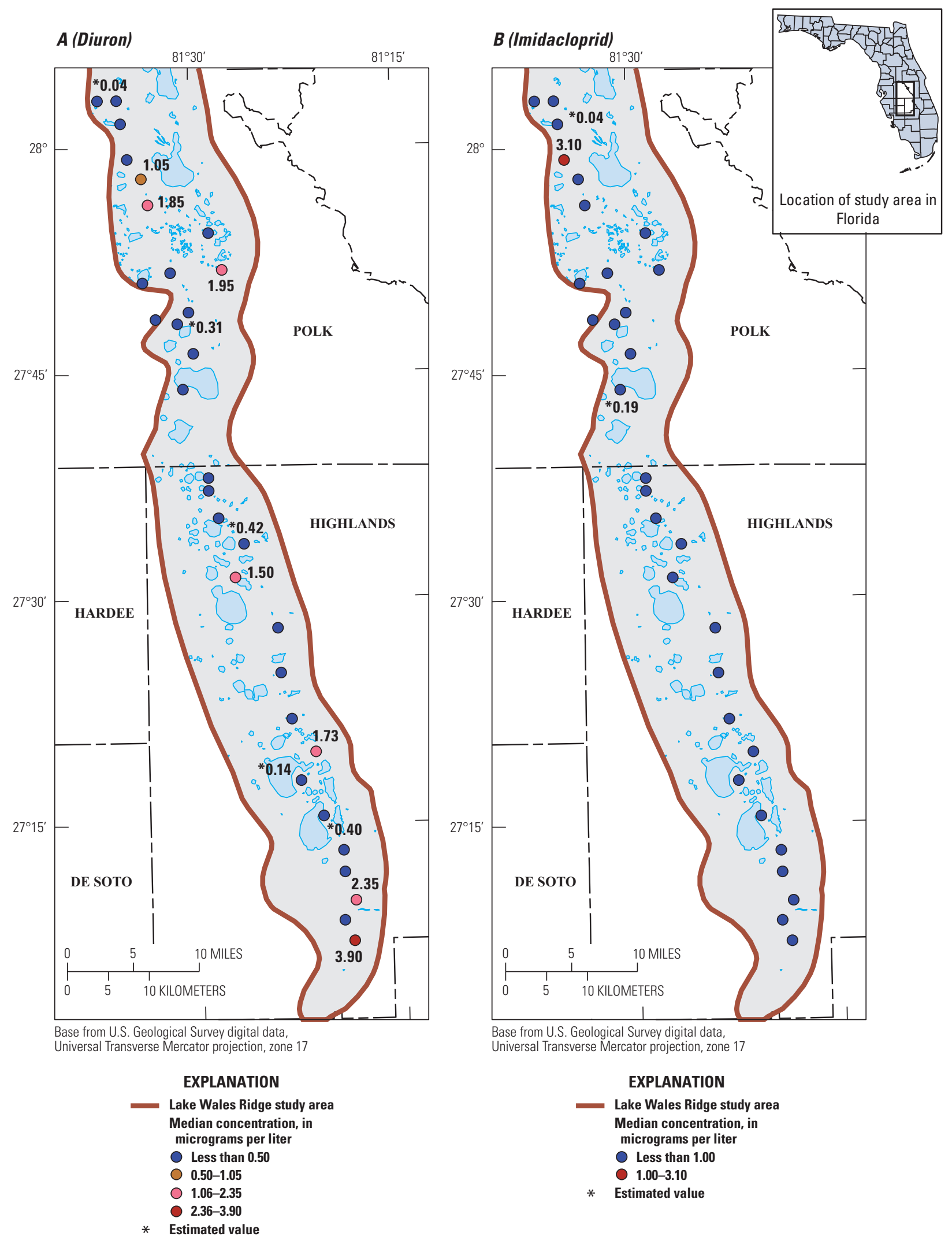

Figure 11. Median concentrations of $(A)$ diuron and $(B)$ imidacloprid in samples from network wells, 0ctober 2001 through January 2005. "Estimated value" refers to medians, determined using the log-probability method, that were below the laboratory reporting level for the analyte. 


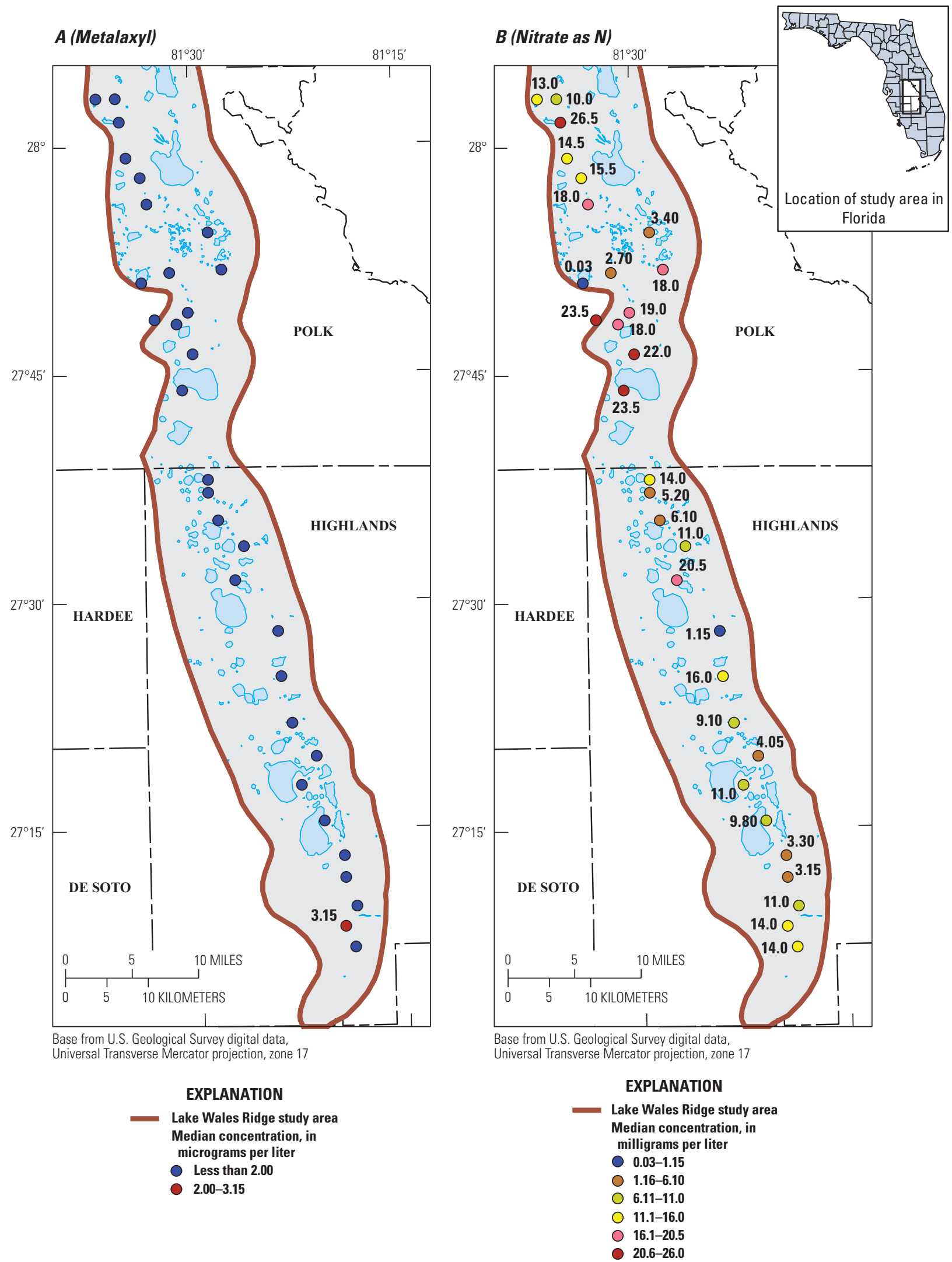

Figure 12. Median concentrations of $(A)$ metalaxyl and $(B)$ nitrate (as $N$ ) in samples from network wells, October 2001 through January 2005. Medians for wells with censored (less than) concentrations were determined using the logprobability method. 


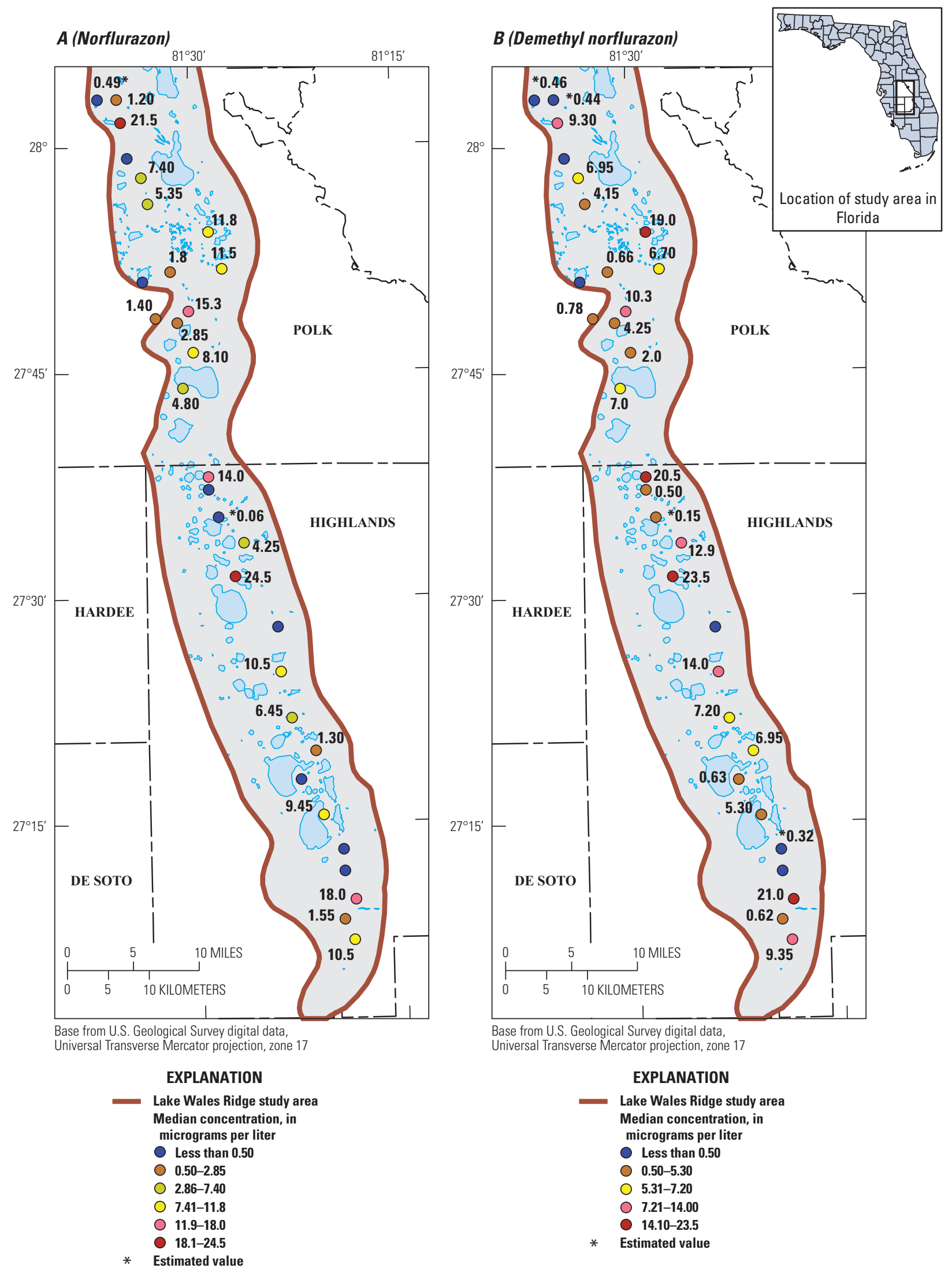

Figure 13. Median concentrations of $(A)$ norflurazon and $(B)$ demethyl norflurazon in samples from network wells, October 2001 through January 2005. "Estimated value" refers to medians, determined using the log-probability method, that were below the laboratory reporting level for the analyte. 


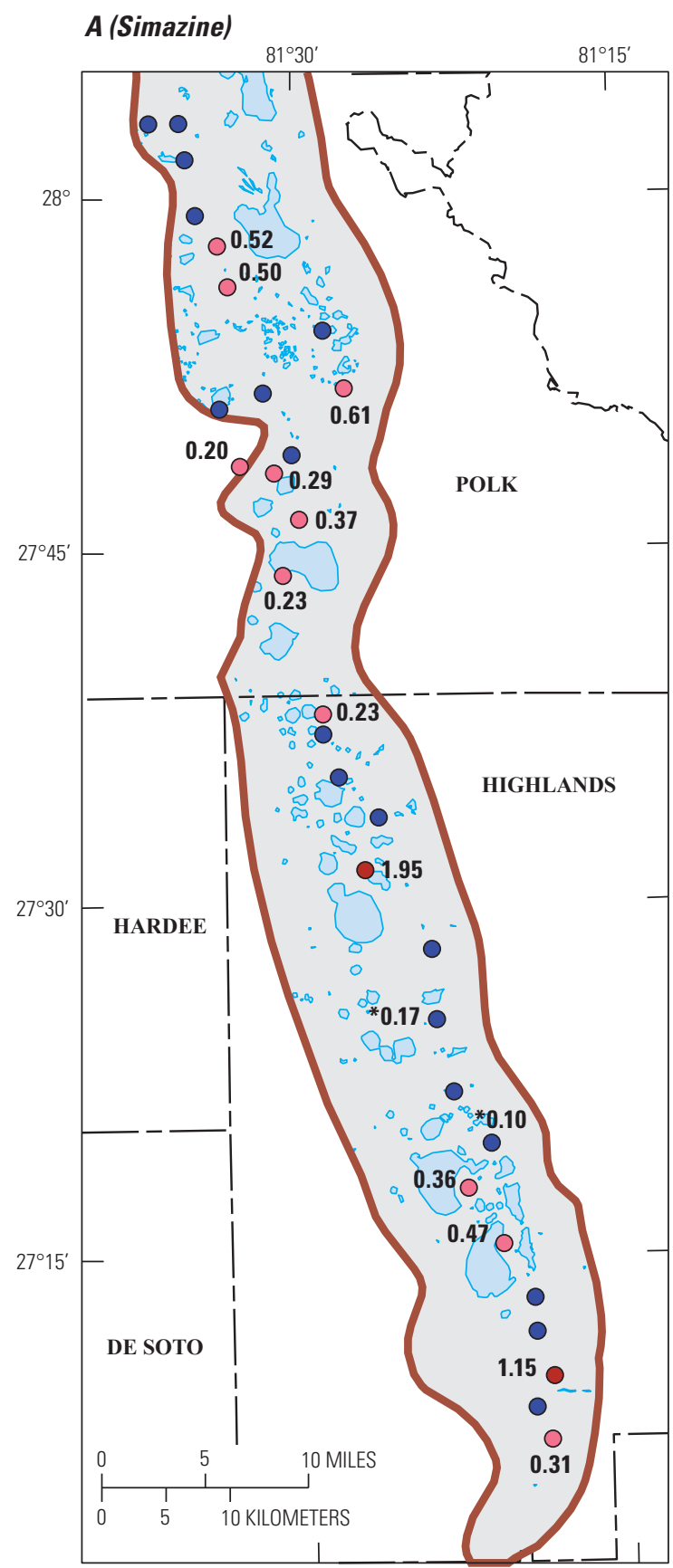

Base from U.S. Geological Survey digital data,

Universal Transverse Mercator projection, zone 17

\section{EXPLANATION}

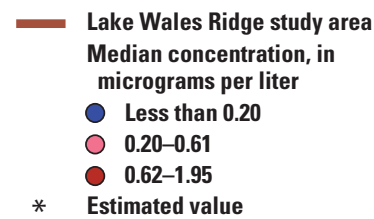

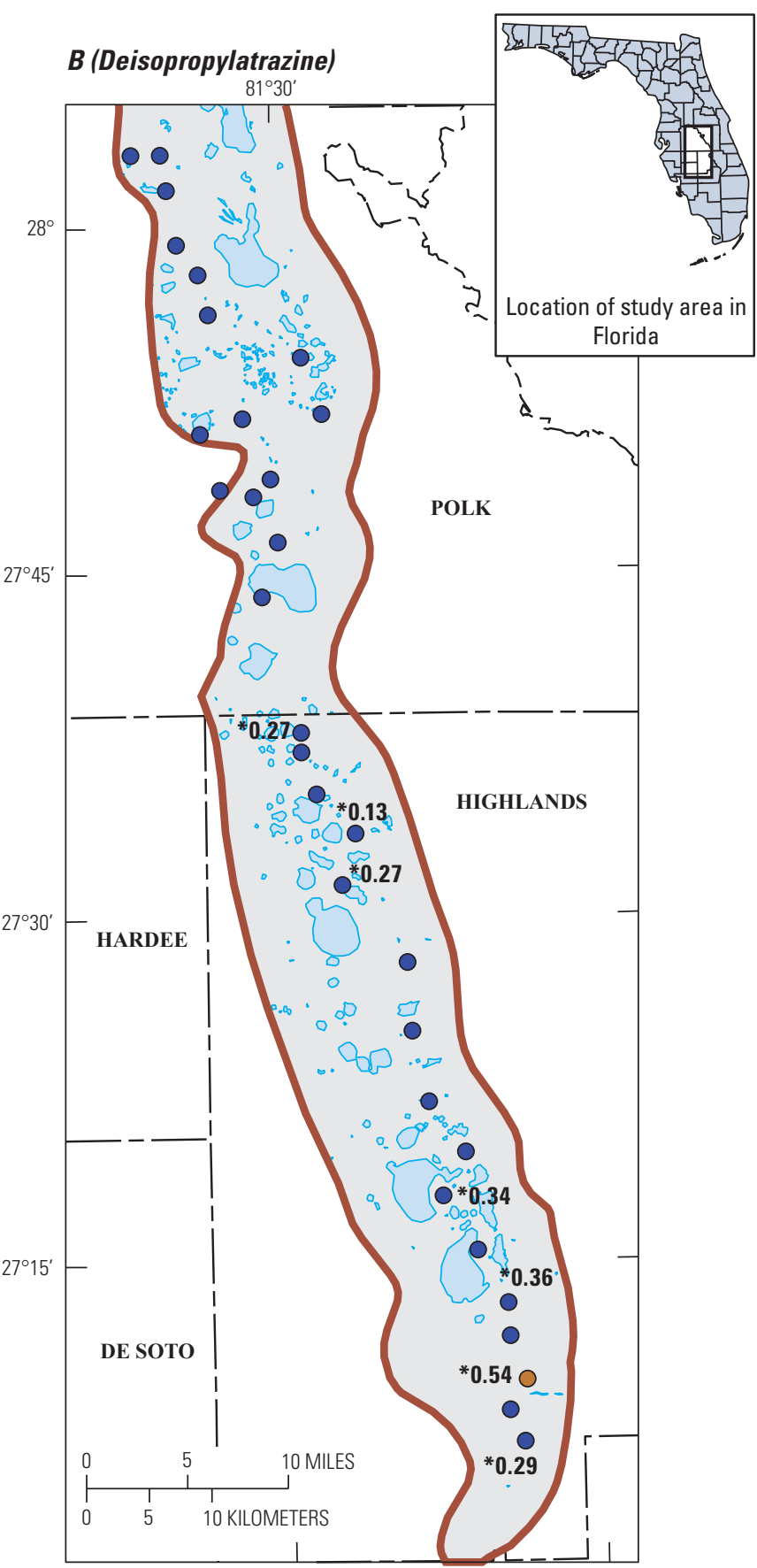

Base from U.S. Geological Survey digital data,

Universal Transverse Mercator projection, zone 17

\section{EXPLANATION}

Lake Wales Ridge study area

Median concentration, in

micrograms per liter

- Less than $\mathbf{0 . 4 0}$

O $\mathbf{0 . 4 0 - 0 . 6 0}$

* Estimated value

Figure 14. Median concentrations of $(A)$ simazine and $(B)$ deisopropylatrazine (DIA) in samples from network wells, October 2001 through January 2005. "Estimated value" refers to medians, determined using the log-probability method, that were below the laboratory reporting level for the analyte. 


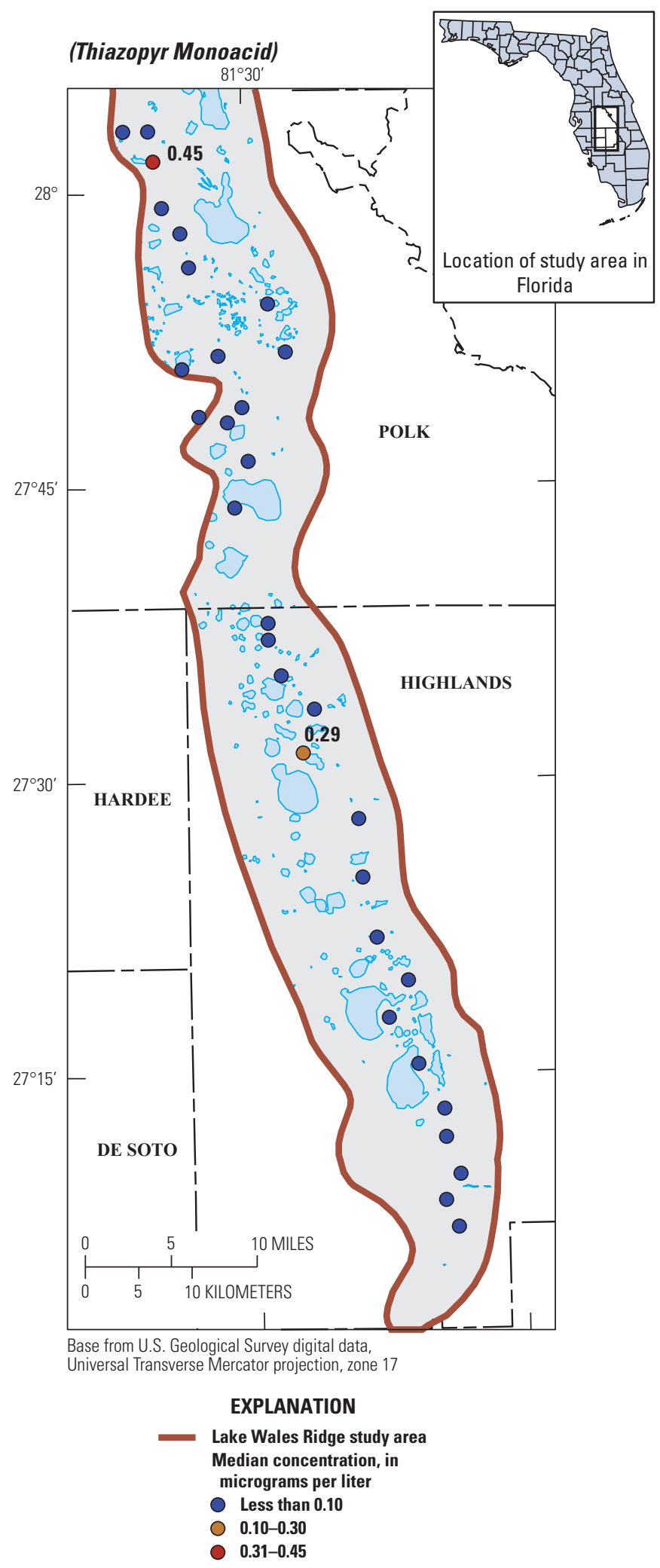

Figure 15. Median concentrations of thiazopyr monoacid in samples from network wells, October 2001 through January 2005.

\section{Summary}

This report provides summaries of pesticide and nitrate sample results, along with contemporaneous information on rainfall patterns and pesticide usage for the period April 1999 through January 2005, the initial 5.75 years of the LWRM (Lake Wales Ridge Monitoring) Network monitoring program. The groundwater quality summaries in the report include quarterly water-quality records of pesticide and nitrate concentrations at 31 wells tapping the surficial aquifer in areas of citrus land use underlain by sandy soils. The depth to top of well screens (that is, water intake zones) in the wells ranged from $9 \mathrm{ft}$ to $130 \mathrm{ft}$ below land surface. Water-table depth ranged from about 4 to $103 \mathrm{ft}$ (median $38 \mathrm{ft}$ ) among the sampled wells, and sampling depth (depth of water table below top of well screen) ranged from the water table to about $38 \mathrm{ft}$. Descriptive statistics for nitrate and each of the detected pesticides, determined using adjustments for censored values and multiple detection levels, included regional summaries (among wells), summaries by well, and maps depicting spatial variability in concentrations.

Of the 44 citrus pesticides and pesticide degradates analyzed, 17 were detected in groundwater samples from network wells between April 1999 and January 2005. Laboratory detection levels for routinely analyzed pesticide compounds typically were in the range of 0.25 to $0.5 \mu \mathrm{g} / \mathrm{L}$. The pesticides and pesticide degradates most often detected, in 87 to 32 percent of the wells, were in order of decreasing prevalence: norflurazon, demethyl norflurazon, simazine, diuron, bromacil, aldicarb sulfone, deisopropylatrazine, and aldicarb sulfoxide. Imidacloprid, metalaxyl, thiazopyr monoacid, oxamyl, and aldicarb were detected less frequently, in 3 to 13 percent of the wells.

During the 2001-2005 period of common record, median values among the wells yielding groundwater pesticide detections typically were less than $1 \mu \mathrm{g} / \mathrm{L}$, with the exception of norflurazon and demethyl norflurazon with median values of 5.9 and $6.7 \mu \mathrm{g} / \mathrm{L}$. Among the highest median concentrations per well, based on samples collected during the 1999-2005 period ( $\mathrm{n}=14$ to 24 samples), were $3.05 \mu \mathrm{g} / \mathrm{L}$ (simazine), $3.90 \mu \mathrm{g} / \mathrm{L}$ (diuron), $6.30 \mu \mathrm{g} / \mathrm{L}$ (aldicarb sulfone), $6.85 \mu \mathrm{g} / \mathrm{L}$ (aldicarb sulfoxide), $22.0 \mu \mathrm{g} / \mathrm{L}$ (demethyl norflurazon), $25.0 \mu \mathrm{g} / \mathrm{L}$ (norflurazon), $89 \mu \mathrm{g} / \mathrm{L}$ (bromacil), and $25.5 \mathrm{mg} / \mathrm{L}$ (nitrate).

In reconnaissance sampling at five Network wells, detected concentrations of triazine pesticide degradates ranged from 0.04 to $2.96 \mu \mathrm{g} / \mathrm{L}$, and included DIA, DDA, DIHA, HS, and HA (deisopropylatrazine, didealkylatrazine, deisopropylhydroxyatrazine, hydroxysimazine, and hydroxyatrazine, respectively). With the exception of HA (which was detected at very low concentrations), simazine likely is the principal source (parent pesticide) of these compounds, because atrazine is not registered for use in Florida citrus. Nitrate concentrations exceeded the $10 \mathrm{mg} / \mathrm{L}$ drinking water standard in one or more groundwater samples from 28 (90 percent) of the 31 sampled wells, and these exceedances occurred in some wells 
with water-table depths exceeding $100 \mathrm{ft}$. Median concentrations of pesticide compounds measured at Network wells during the 2001-2005 period did not exhibit any pronounced or consistent spatial patterns; however, nitrate concentrations typically were greater in sampled wells in the northern part of the study area compared to the southern part.

During the April 1999 through January 2005 period, Florida human-health GCs (guidance concentrations) for groundwater were exceeded in sampled concentrations including seven of the analyzed pesticides and degradates and (or) their parent-degradate sums: aldicarb sulfone and aldicarb sulfoxide (4 wells), the sum of aldicarb and its degradates ( 6 wells), simazine ( 2 wells), the sum of simazine and DIA ( 3 wells), diuron ( 2 wells), and bromacil ( 1 well). The $105 \mu \mathrm{g} / \mathrm{L} \mathrm{GC}$ for norflurazon and its degradate, revised from $280 \mu \mathrm{g} / \mathrm{L}$ during 2012, was exceeded for the sum of norflurazon and demethyl norflurazon (1 well). Concentrations of aldicarb plus its degradates and simazine plus DIA fluctuated above and below health-guidance benchmarks, both in groundwater from shallow wells and from wells as deep as 40 to $55 \mathrm{ft}$. Nitrate concentrations exceeded the GC in 28 of the 31 wells, including wells with screen depths exceeding $120 \mathrm{ft}$.

Although there often was consistency in detections of some of the pesticides in samples from individual wells over time, large variations in concentrations of most of the detected pesticides occurred at some wells between quarterly samples. The pesticide compounds that exhibited the greatest temporal consistency in detections included norflurazon, demethyl norflurazon, simazine, aldicarb sulfone, and aldicarb sulfoxide, typically detected in more than 50 percent of samples from the wells where detections occurred; however, relatively large temporal fluctuations in pesticide concentrations occurred between quarterly samples at a given well. The median relative interquartile range of sampled concentrations by well ranged from 87 to 540 percent among the 10 pesticide compounds evaluated, with highest temporal variability occurring in concentrations of imidacloprid, aldicarb sulfoxide, aldicarb sulfone, bromacil, and diuron.

The water-quality summaries in this report provide an overview of the conditions during 1999-2005 and a basis for comparison with other periods of the long-term record. Several factors will likely influence agrichemical concentrations in groundwater sampled from the LWRM Network subsequent to 2005. Such factors include changes in pesticide use and regulations; implementation of fertilizer best management practices in Ridge citrus croplands; the conversion of citrus croplands to developed areas in the vicinity of some LWRM Network wells; and the onset (in 2005) and rapid spread of citrus greening disease in Florida's citrus croplands, which has initiated changes in citrus pesticide usage practices.

\section{References}

Adamski, J.C., and German, E.R., 2004, Hydrology and quality of ground water in Orange County, Florida: U.S. Geological Survey Water-Resources Investigation Report 03-4257, 113 p.

Aerts, M.J., and Nesheim, O.N., 2000, Florida crop/pest management profiles - Citrus (oranges/grapefruit): Gainesville, Fla., Pesticide Information Office, Institute of Food and Agricultural Sciences CIR 1241, University of Florida, $15 \mathrm{p}$.

Albrigo, L.G., Buker, R.S., Burns, J.K., Castle, W.S., and others, 2005, The impact of four hurricanes in 2004 on the Florida citrus industry-Experiences and lessons learned: Proceedings of the Florida State Horticultural Society, v. 118, p. 66-74.

Barbash, J.E., and Resek, E.A., 1996, Pesticides in ground water-Distribution, trends, and governing factors: Chelsea, Michigan, Ann Arbor Press, Pesticides in the Hydrologic System series, V.2, p.109-111.

Barcelo, M.D., Slonena, D.L., Camp, S.C., and Watson, J.D., 1990, Ridge II - A hydrogeologic investigation of the Lake Wales Ridge: Brooksville, Florida, Southwest Florida Water Management District Report, 130 p. and appendix.

Barr, G.L., 1992, Ground-water contamination potential and quality in Polk County, Florida: U.S. Geological Survey Water-Resources Investigations Report 92-4086, 92 p.

Boman, B.J., ed., 2002, Water and Florida citrus-Use, regulation, irrigation, systems, and management: Gainesville, Fla., Institute of Food and Agricultural Sciences, Special Publication, no. 281, 604 p.

Bossak, B.H., 2004, "X" marks the spot—Florida is the 2004 hurricane bull's-eye: EOS, American Geophysical Union, v. 85 , no. 50, p. 541 and 545 .

Brandt, E., 1995, Annual herbicide, insecticide, and fungicide use on individual crops and turfgrass in the United States for a typical year around 1992, in Barbash, J.E., and Resek, E.A., 1996, Pesticides in ground water-Distribution, trends, and governing factors: Chelsea, Michigan, Ann Arbor Press, Pesticides in the Hydrologic System series, v. 2, p. 109-111.

Brock, M., and Rygiel, T., 2003, The determination of inorganic anions in water by ion chromatography: Tallahassee, Fla., Florida Department of Agriculture and Consumer Services, Pesticide Laboratory, 11 p. 
Choquette, A.F., Freiwald, R.S., and Kraft, C.L., 2012, Sampling history and 2009-2010 results for pesticides and inorganic constituents monitored by the Lake Wales Ridge Groundwater Network, Central Florida: U.S. Geological Survey Open-File Report 2012-1231, 19 p.

Choquette, A.F., and Kroening, S.E., 2005, Elevated nitrate, pesticides, and pesticide degradates in ground water and lakes on the Lake Wales Ridge, a unique hydrologic and biologic region in central Florida, in U.S. Geological Survey Science in Florida: U.S. Geological Survey Open-File Report 2005-1213, Florida Integrated Science Center Meeting, May 2005, Orlando, Fla., Proceedings.

Choquette, A.F., and Kroening, S.E., 2009, Water quality and evaluation of pesticides in lakes in the Ridge citrus region of central Florida: U.S. Geological Survey Scientific Investigations Report 2008-5178, 55 p.

Choquette, A.F., Moore, D.K, DeHaven, E.C., Haber, J.D., and Turner, R.M., 2003, A litmus area for transport of agricultural chemicals into ground water and lakes, central Florida: May 12-14, 2003, American Water Resources Association, 2003 Spring Specialty Conference - Agricultural Hydrology and Water Quality, Kansas City, Mo., Proceedings, American Water Resources Association Technical Publication Series No. TPS-03-01.

Choquette, A.F., and Sepulveda, A.A., 2000, Design of a shallow ground-water network to monitor agricultural chemicals, Lake Wales Ridge, Central Florida: U.S. Geological Survey Water-Resources Investigations Report 2000-4134, 35 p. (Also available at http://pubs.er.usgs.gov/publication/ wri004134.)

Choquette, A.F., Turner, R.D., Haber, J.D., Lucas, P.A., Daiker, D.H., and DeHaven, E.C., 2005, Temporal variability of agricultural chemicals in ground water and implications for water-quality sampling: The 15th Tennessee Water Resources Symposium, April 13-15, 2005, Burns, Tenn., American Water Resources Association, Proceedings, $\mathrm{p}$. 2B-6 - 2B-14. (Also available at http://tnawra.er.usgs.gov/ Library/Proceedings15th.pdf.)

Duerr, A.D., Hunn, J.D., Lewelling, B.R., and Trommer, J.T., 1988, Geohydrology and 1985 water withdrawals of the aquifer systems in southwest Florida, with emphasis on the intermediate aquifer system: U.S. Geological Survey WaterResources Investigations Report 87-5259, 115 p.

Fishel, F.M., 2009, Specifically regulated pesticides in Florida-Bromacil: Florida Cooperative Extension, Institute of Food and Agricultural Sciences, University of Florida, UF/ IFAS EDIS (Electronic Data Information source) Publication No. PI-75, 1 p. (Also available at http://edis.ifas.ufl. edu/pi112.)
Florida Department of Agriculture and Consumer Services, 1995, Protocol guidelines for pesticide field studies in Florida: Tallahassee, Fla., Bureau of Pesticides, 33 p.

Florida Department of Environmental Protection, 2002, Department of Environmental Protection standard operating procedures for field activities: Florida Department of Environmental Protection Document DEP-SOP-001/01, [variously paged].

Florida Department of Environmental Protection, 2012a, Back $\neg$ ground water quality monitoring network database: accessed March 4, 2012, at http://www.dep.state.fl.us/water/ monitoring/bn_net.htm.

Florida Department of Environmental Protection, 2012b, Very Intense Study Area (VISA) database: accessed March 4, 2012, at http://www.dep.state.fl.us/water/ monitoring/visa_net.htm.

Focasio, M.J., Reilly, T.E., Rupert, M.G., and Helsel, D.R., 2002, Assessing ground-water vulnerability to contamination - providing scientifically defensible information for decision makers: U.S. Geological Survey Circular 1224, 33 p. (Also available at http://water.usgs.gov/pubs/ circ/2002/circl224/.)

German, E.R., 1996, Analysis of nonpoint-source groundwater contamination in relation to land use-Assessment of non-point source contamination in central Florida: U.S. Geological Survey Water-Supply Paper 2381-F, 60 p.

Gianessi, L.P., and Silvers, C.S., 2000, Trends in crop pesticide use-Comparing 1992 and 1997: Washington, D.C., National Center for Food and Agricultural Policy, 165 p.

Gilliom, R.J., Barbash, J.E., Crawford, C.G., Hamilton, P.A., Martin, J.D., Nakagaki, Naomi, Nowell, L.H., Scott, J.C., Stackelberg, P.E., Thelin, G.P., and Wolock, D.M., 2006, Herbicides in Florida ground water, in The quality of our Nation's waters-Pesticides in the Nation's streams and ground water, 1992-2001: U.S. Geological Survey Circular 1291, p. 136.

Helsel, D.R., 2005, Nondetects and data analysis-Statistics for censored environmental data: Hoboken, New Jersey, Wiley and Sons, Inc., 250 p.

Helsel, D.R., and Cohn, T.A., 1988, Estimation of multiply descriptive statistics for multiply censored water quality data: Water Resources Research, v.24, no.12, p.1997-2004.

Hornsby, A.G., Rao, P.S.C., and Jones, R.L., 1990, Fate of aldicarb in the unsaturated zone beneath a citrus grove: Water Resources Research, v. 26, no. 10, p. 2287-2302.

Insightful Corporation, 2001, S-Plus 6 for windows, users guide: Seattle, Wash., Insightful Corp., 688 p. 
Jones, R.L., Hornsby, A.G., Rao, P.S.C., and Anderson, M.P., 1987, Movement and degradation of aldicarb residues in the saturated zone under citrus orchards on the Florida ridge: Journal of Contaminant Hydrology, v. 1, p. 265-285.

Lee, E.A., Strahan, A.P., and Thurman, E.M., 2002, Methods of analysis by the U.S. Geological Survey Organic Geochemistry Research Group-Determination of triazine and phenylurea herbicides and their degradation products in water using solid-phase extraction and liquid chromatography/mass spectrometry: U.S. Geological Survey Open-File Report 02-436, 26 p.

Morse, L.A., 1999, Comprehensive quality assurance plan \#900456 for the Ambient Monitoring Section: Tallahassee, Florida, Florida Department of Environmental Protection, [variously paged].

National Academy of Sciences, 2010, Strategic planning for the Florida citrus industry-Addressing Citrus Greening disease: Washington, D.C., National Academies Press, 4 p.

National Agricultural Statistics Service, 2005, Historical reports, citrus summaries: U.S. Department of Agriculture (Also available at http://www.nass.usda.gov/Statistics_by_ Subject/index.php? sector $=$ CROPS.)

National Association of State Departments of Agriculture Research Foundation, 2000, Federal environmental laws affecting agricul $\neg$ ture: National Center for Agricultural Research and Law, 45 p. (Also available at http://www2.ca.uky.edu/smallflocks/Factsheets/Federal_ environmental_laws_affecting_ag.pdf.)

National Oceanic and Atmospheric Administration, 2010, 1932-2005 Climatological data-Annual summaries for Florida database: accessed August 13, 2012, at http://cdo. ncdc.noaa.gov/ancsum/ACS.

Ouellette, D.P., Hansard, Paul, and DeHaven, Eric, 1998, Ground-water quality and agricultural land use in the Polk County Very Intense Study Area (VISA): Florida Department of Environmental Protection, Ambient Program Newsletter, v. 2, no. 2, p. 1-6.

Page, M., and Stepp, J., 2003, The analysis of organic acids and acid esters in drinking water by liquid chromatography/ mass spectrometry: Tallahassee, Fla., Florida Department of Agriculture and Consumer Services, Pesticide Laboratory, $12 \mathrm{p}$.

Paramasivam, S., and Sajwan, K.S., 2001, Estimation of nitrate leaching in an entisol under optimum citrus production: Journal of the Soil Science Society of America, v. 65, p. 914-921.

Parsons, Larry, and Boman, Brian, 2006, Best management practices for Florida citrus: HortTechnology, v. 16, no. 3, p. 389-393.
Rogers, M.E., 2011, Asian citrus psyllid management in Florida-Past, present, and future: Gainesville, University of Florida, Institute of Food and Agricultural Sciences, Florida Pesticide Review Council Meeting, May 2011, accessed August 13, 2012, at http://www.flaes.org/pesticide/ pesticidereviewcouncil.html and slide presentation at http://www.flaes.org/pdf/PRC_2011_Presentations.pdf.

Rogers, M.E., Stansly, P.A., and Stelinski, L.L., 2010, Citrus health management areas (CHMA's) —-Developing a psyllid management plan: Gainesville, University of Florida, Institute of Food and Agricultural Sciences Extension Publication, accessed August 13, 2012, at http://www.crec. ifas.ufl.edu/extension/chmas/PDF/CHMA_spray\%20 plan_10_11_10.pdf and http://www.crec.ifas.ufl.edu/ exten $\neg$ sion/chmas/index.shtml.

Rygiel, T., 2003, The analysis of N-methylcarbamoyloximes and N-methyl-carbamates in water by direct aqueous injection HPLC with post column derivatization: Tallahassee, Fla., Florida Department of Agriculture and Consumer Services, Pesticide Laboratory, 13 p.

Sacks, L.A., Swancar, Amy, and Lee, T.M., 1998, Estimating ground-water exchange with lakes using water-budget and chemical mass-balance approaches for ten lakes in ridge areas of Polk and Highlands Counties, Florida: U.S. Geological Survey Water-Resources Investigations Report 98-4133, $52 \mathrm{p}$.

Scribner, E.A., Thurman, E.M., and Zimmerman, L.R., 1999, Analysis of selected herbicide metabolites in surface and ground water of the United States: U.S. Geological Survey Water Resources Investigations Report 99-4018B, 11 p.

Sepulveda, Nicasio, 2002, Simulation of ground-water flow in the Intermediate and Floridan Aquifer Systems in peninsular Florida: U.S. Geological Survey Water-Resources Investigations Report 02-4009, 130 p.

Shahane, A.N., 2003, Summary of agricultural pesticide usage in Florida-1999-2002: Tallahassee, Florida Department of Agriculture and Consumer Services, 108 p.

Silvanima, Jay, Hansard, Paul, and Ouellette, David, [n.d.], Florida Ground Water Quality Monitoring NetworkSummary 1994-1997: Florida Department of Environmental Protection database, accessed February 14, 2012, at http://waterwebprod.dep.state.fl.us/ambient/triennial/ default.htm.

Southwest Florida Water Management District, 1998, 19941995 digital orthophoto quadrangles with citrus land use delineated by Dianna Burdick, Southwest Florida Water Management District, Brooksville, Fla. 
Southwest Florida Water Management District, 2006, Standard operating procedures for the collection of water quality samples: Tampa, Fla., Water Quality Monitoring Program, Resource Conservation and Data Department, 54 p. and appendixes.

Spechler, R.M., 2010, Hydrology and groundwater quality of Highlands County, Florida: U.S. Geological Survey Scientific Investigations Report 2010-5097, 84 p. (Also available at http://pubs.er.usgs.gov/publication/sir20105097.)

Spechler, R.M., and Kroening, S.E., 2007, Hydrology of Polk County, Florida: U.S. Geological Survey Scientific Investigations Report 2006-5320, 114 p. (Also available at http://pubs.er.usgs.gov/publication/sir20065320.)

State of Florida, 1993, Restrictions on the use of bromacil in citrus: Florida Administrative Code, Rule 5E-8.038 in volume 19, Number 44, November 5, 1993, p. 6424, Florida Administrative Weekly.

State of Florida, 1995, Restrictions on the use of bromacil in citrus: Florida Administrative Code, Rule 5E-2.038. (Also available at $h t t p: / / w w w$ flaes.org/statutesandrules.html.)

State of Florida, 2002a, Florida aldicarb rule: Florida Administrative Code, Rule 5E-2.028. (Also available at $h t t p: / / f l a e s$. org/statutesandrules.html).

State of Florida, 2002b, Nitrogen best management practices (BMPs) for Florida ridge citrus: Florida Statute Title XXXV, Chapter 576.045(6)(a)2, Rule 5E-1.023. (Also available at $h t t p: / / f l a e s . o r g / s t a t u t e s a n d r u l e s . h t m l$.

State of Florida, 2005, Contaminant cleanup target levels, table 1-Groundwater and surface water cleanup target levels: Florida Administrative Code, Rule 62-777, accessed December 1, 2010, at http://www.dep.state.fl.us/waste/ quick_topics/rules/.

State of Florida, 2012, Florida drinking-water standards, monitoring, and reporting: Florida Administrative Code, Rule 62-550, accessed July 1, 2012, at http://www.dep.state.fl.us/ legal/Rules/drinkingwater/62-550.pdf.

Stauffer, R.E., 1991, Effects of citrus agriculture on ridge lakes in central Florida: Water, Air, and Soil Pollution, v. 59, p. 124-144.

Tihansky, A.B., and Sacks, L.A., 1997, Evaluation of nitrate sources using nitrogen-isotope techniques in shallow ground water within selected lake basins in the Central Lakes District, Polk and Highlands Counties, Florida: U.S. Geological Survey Water-Resources Investigations Report 97-4207, $28 \mathrm{p}$.
Tola, Shane, and Moody, P.H., 2007, The preparation and analysis of thiazapyr, thiazapyr monoacid, and bentazon in groundwater or drinking water by liquid chromatography/ mass spectrometry: Tallahassee, Fla., Florida Department of Agriculture and Consumer Services, Pesticide Laboratory, PLS-SOP No. 65, rev. 4, 9 p.

University of Florida, 2005, Final Technical Report-Development of Cleanup Target Levels (CTLs) for Chapter 62-777, Florida Administrative Code (F.A.C.): Gainesville, Fla., Center for Environmental and Human Toxicology, University of Florida, $310 \mathrm{p}$.

U.S. Department of Agriculture, 1996 through 2006, Agricultural Chemical Usage-Fruit Summary, published biennially: National Agricultural Statistics Service, Chemical Usage Program. (Also available at http://usda. mannlib.cornell.edu/MannUsda/viewDocumentInfo. do? documentID=1567.)

U.S. Environmental Protection Agency, 2010, Agreement to terminate all uses of aldicarb. (Also available at $h t t p: / /$ www.epa.gov/oppsrrd1/REDs/factsheets/aldicarb_fs.html, accessed 3/31/2011.)

U.S. Environmental Protection Agency, 2011, The 2011 edition of the drinking-water standards and health advisories: Washington, D.C., U.S. Environmental Protection Agency, Office of Water, Report EPA 820-R-11-002, 18 p. (Also available at http://water.epa.gov/action/advisories/drinking/ upload/dwstandards2011.pdf.)

Wilson, C., Boman, B., and Hebb, J., 2002, Environmental concerns-Pesticides, chap. 6 of Boman, B., ed., 2002, Water and Florida citrus: Gainesville, Fla., University of Florida Institute of Food and Agricultural Research, p. 51-66.

Yobbi, D.K., 1996, Analysis and simulation of ground-water flow in Lake Wales Ridge and adjacent areas of central Florida: U.S. Geological Survey Water-Resources Investigations Report 94-4254, 82 p. 
For further information about this publication contact:

Director

U.S. Geological Survey

Florida Water Science Center

4446 Pet Lane, Suite 108

Lutz, FL 33559

Or visit the Florida Water Science Center Web site at http://fl.water.usgs.gov

Prepared by the Raleigh Publishing Service Center 
$\stackrel{\Phi}{=}$ 